\title{
Incorporation of Rare Earths and Yttrium in Calcite: A Critical Re-evaluation
}

\author{
Peter Möller ${ }^{1}$ (D) Marco De Lucia ${ }^{1}$
}

Received: 28 August 2019 / Accepted: 3 February 2020 / Published online: 12 February 2020

(c) The Author(s) 2020

\begin{abstract}
The reported partition coefficients of REE with calcite are reviewed and critically discussed. In some of the reported experimental sets, REE concentrations are found to be supersaturated with respect to individual $\operatorname{REE}_{2}\left(\mathrm{CO}_{3}\right)_{3}$ but never to $\operatorname{REE}(\mathrm{OH})_{3}$. Although the solutions are unsaturated with respect to individual REY carbonates, REY including $\mathrm{Y}$ are incorporated in calcite surfaces, where they are overgrown by calcite. Charge balances may be obtained by building $\left\{\mathrm{REY}-\mathrm{Na}-\left(\mathrm{CO}_{3}\right)_{2}\right\}_{n}$ or by exchange of $2 \mathrm{Ca}^{2+}$ against $\mathrm{REY}^{3+}+$ blank space calcite lattice. These surface compounds may either be homogeneously distributed or clustered. Both the size and frequency of clusters increase with [REY]/ $[\mathrm{Ca}]$ or $\left[\Sigma \mathrm{REY}^{3+}\right] /\left[\mathrm{Ca}^{2+}\right]$ in solution. If these surface precipitates are removed into solutions saturated with respect to $\Sigma \mathrm{REE}_{2}\left(\mathrm{CO}_{3}\right)_{3}$, they start growing in the aqueous phase. In this case, the apparent $D_{\mathrm{REY}}$ and $k_{\mathrm{REY}}$ values decrease with increasing REY concentrations in solution. In previous studies, only the individual distribution coefficients are reported not considering that the entirety of REY determines their behavior in partitioning. Given enough time, these surface clusters equilibrate with the aqueous phase before being overgrown by calcite. In the double logarithmic plots of $\{\mathrm{REY}\} /\{\mathrm{Ca}\}$ versus $[\mathrm{REY}] /[\mathrm{Ca}]$ or $\left[\mathrm{REY}^{3+}\right] /\left[\mathrm{Ca}^{2+}\right]$, two relationships evolve characterizing the REY distribution in marine calcite and experimental calcites grown in $\mathrm{Mg}^{2+}$-free solutions. The double logarithmic plots of partition coefficients of $\mathrm{REY}_{i}^{3+}$ in calcite grown from seawater show a slope exceeding unity, whereas those from fluids without $\mathrm{Mg}^{2+}$ depict slopes less than unity being both in contrast to the Henderson-Kracek rule.
\end{abstract}

Keywords Partitioning of rare earths with calcite $\cdot$ Formation of REY-Na carbonate compounds · Homogeneous partitioning · Individual versus entirety of rare earths' partitioning between calcite and ambient solution

Peter Möller

pemoe@gfz-potsdam.de

1 Helmholtz Centre Potsdam, German Research Centre for Geosciences GFZ, Section 3.4,

Telegrafenberg, 14473 Potsdam, Germany 


\section{Introduction}

Rare earth elements (REE) and yttrium (Y) behave similarly and are henceforth referred to as REY (Bau and Dulski 1995). When Y is absent in cited experiments, the term REE is used. This suite of REY is ubiquitous in nature and is particularly incorporated in omnipresent calcite. The heterogeneous, onion-shell-like (Eq. 1) and homogeneous partitioning (Eq. 2) was first applied to describe the partition of $\mathrm{Ra}^{2+}$ with barium sulfate (Doener and Hoskins 1925) and chromate (Henderson and Kracek 1927), respectively.

$$
\begin{gathered}
k=\log \left(\left\{\mathrm{REY}_{\mathrm{in}}\right\} /\left\{\mathrm{REY}_{\mathrm{fin}}\right\}\right) / \log \left(\left[\mathrm{Ca}_{\mathrm{in}}\right] /\left[\mathrm{Ca}_{\text {fin }}\right]\right) \\
D_{i}=\left\{X_{\mathrm{REY}_{i}}\right\} /\left\{X_{\mathrm{Ca}}\right\} /\left(\left[\mathrm{REY}_{i}\right] /[\mathrm{Ca}]\right)
\end{gathered}
$$

$X=$ mole fraction of individual REE related to the entirety of cations in calcite; indices: $i=$ individual REE; in =initial; fin $=$ final; \{\} and [ ] indicate total concentrations of elements in solid and aqueous phases, respectively. Ionic charges are only given where specific ionic species are addressed; no charges indicate total concentrations.

The experimental determinations of the homogeneous REY partition coefficients, $\mathrm{D}_{R E Y}$, show widely scattering results (Fig. 1) in calcite precipitation under both different experimental conditions and applied $\mathrm{REE}^{3+}$ concentrations in parent solutions (Table 1). There are mainly four different procedures by which REE partition coefficients with calcite are determined:

1. REE in diagenetic marine carbonates and reefal microbialites are related to REE in seawater (Fig. 1a). Parekh et al. (1977) extrapolated the coprecipitated fraction of REE in plots of REE in limestone samples versus their REE in associated acid insoluble residue. The derived apparent $D_{\mathrm{REE}}$ values decrease from 1388 (La) to $464(\mathrm{Lu})$. Scherer and Seitz (1980) analyzed calcitic cements from coral reefs of the Bahamas with about $15 \mathrm{~mol} \% \mathrm{MgCO}_{3}$. After oxidation of the organic matter by $\mathrm{H}_{2} \mathrm{O}_{2}$ for $24 \mathrm{~h}$, the acid insoluble residue was determined. With the help of these residues, the individual, total REE abundance in carbonates was corrected and related to individual $\left[\mathrm{REE}_{i}\right]$ in modern seawater yielding $D_{\mathrm{REE}}$ values between 120 and 530 for La and Sm, respectively. The trend of average $D_{\text {REE }}$ values of $296 \pm 30$ for Heron microbialites, Great Barrier Reef, Australia (Webb and Kamber 2000) and 212-256 (except Ce with 327) in carboniferous to quaternary limestones from Japan (Toyama and Terakado 2019) resemble those reported by Scherer and Seitz (1980). After ultrasonically removing of Fe-Mn coatings in a reducing bath, Palmer (1985) determined REE abundance in calcitic foraminiferal skeletons from the Atlantic. The removed coatings contained about 1000 times more REE than the remaining calcite skeletons with $D_{\text {REE }}$ values of $125(\mathrm{La})$ and $73(\mathrm{Yb})$.

2. Steady-state condition in suspension of $5 \mathrm{~g}$ of calcite seeds in $2 \mathrm{~L}$ of phosphate-cleaned seawater was achieved by bubbling a $\mathrm{CO}_{2} / \mathrm{N}_{2}$ mixture with $\mathrm{pCO}_{2}$ of 0.0031 , additional stirring by glass propeller and constant addition of calcite-saturated solution containing the REE spike (Zhong and Mucci 1993, 1995). The determination of the quantity of overgrowth by chemical means was not easy because of recovering all calcite sticking to the walls of the reactor. Their reported logarithmic $D_{\text {REE }}$ values decrease from 3.6 to 1.9 for La and Yb, respectively (Fig. 1b). Tanaka and Kawabe (2006) precipitated calcite on seed crystals suspended in $\mathrm{Ca}^{2+}-\mathrm{Na}^{+}$solution by bubbling $\mathrm{N}_{2}$ containing $1 \%$ of $\mathrm{CO}_{2}$ through the solution and operating a magnetic stirrer chip in order to yield 

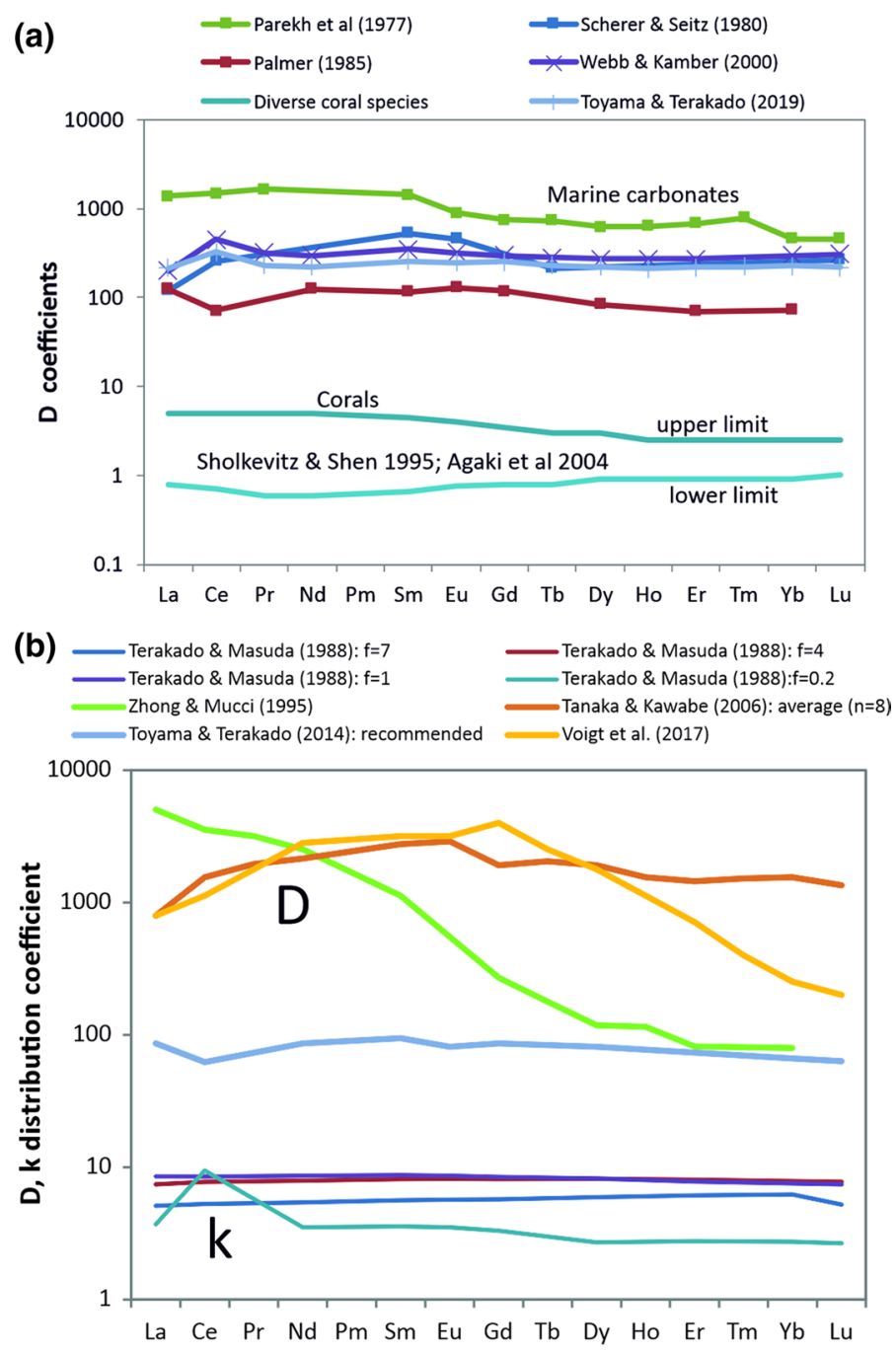

Fig. 1 Compilation of distribution coefficients $D_{i}$ and $k_{i}$ of $\mathrm{REE}^{3+}$ in partitioning with calcite. a experimental results; b derived from analyses of limestone (Parekh et al. 1977), Mg-calcite cements of reefs (Scherer and Seitz 1980), and averages of biogenic carbonates of various coral species (Sholkovitz and Shen 1995; Agaki et al. 2004; Wyndam et al. 2004), all related to $\mathrm{REE}^{3+}$ in modern seawater

a homogeneous overgrowth on calcite seeds. Their initial REY concentrations ranged from $10 \mathrm{ppb}$ in general and $20 \mathrm{ppb}$ for $\mathrm{Pr}, \mathrm{Sm}, \mathrm{Tb}$ and $\mathrm{Tm}$. The calcite overgrowth was derived from charge and mass balances. The developed $\log \left(D_{\mathrm{REE}}\right)$ values cover a range between 2.5 and 3.6 with a broad maximum of the intermediate REE (Fig. 1b). The uncertainty of $D_{\text {REE }}$ values between the extreme runs is about a factor of 3.7. Voigt et al. (2017) reported $\log \left(D_{\mathrm{REE}}\right)$ values of runs with either $\mathrm{La}$ or $\mathrm{Yb}$ and with both elements together. Using the constant addition technique, the experiments were performed under 1 atm $\mathrm{CO}_{2}, \mathrm{pH}$ 6-6.4 and variable amounts of seeds. $\log \left(D_{\mathrm{REE}}\right)$ decreases with both 


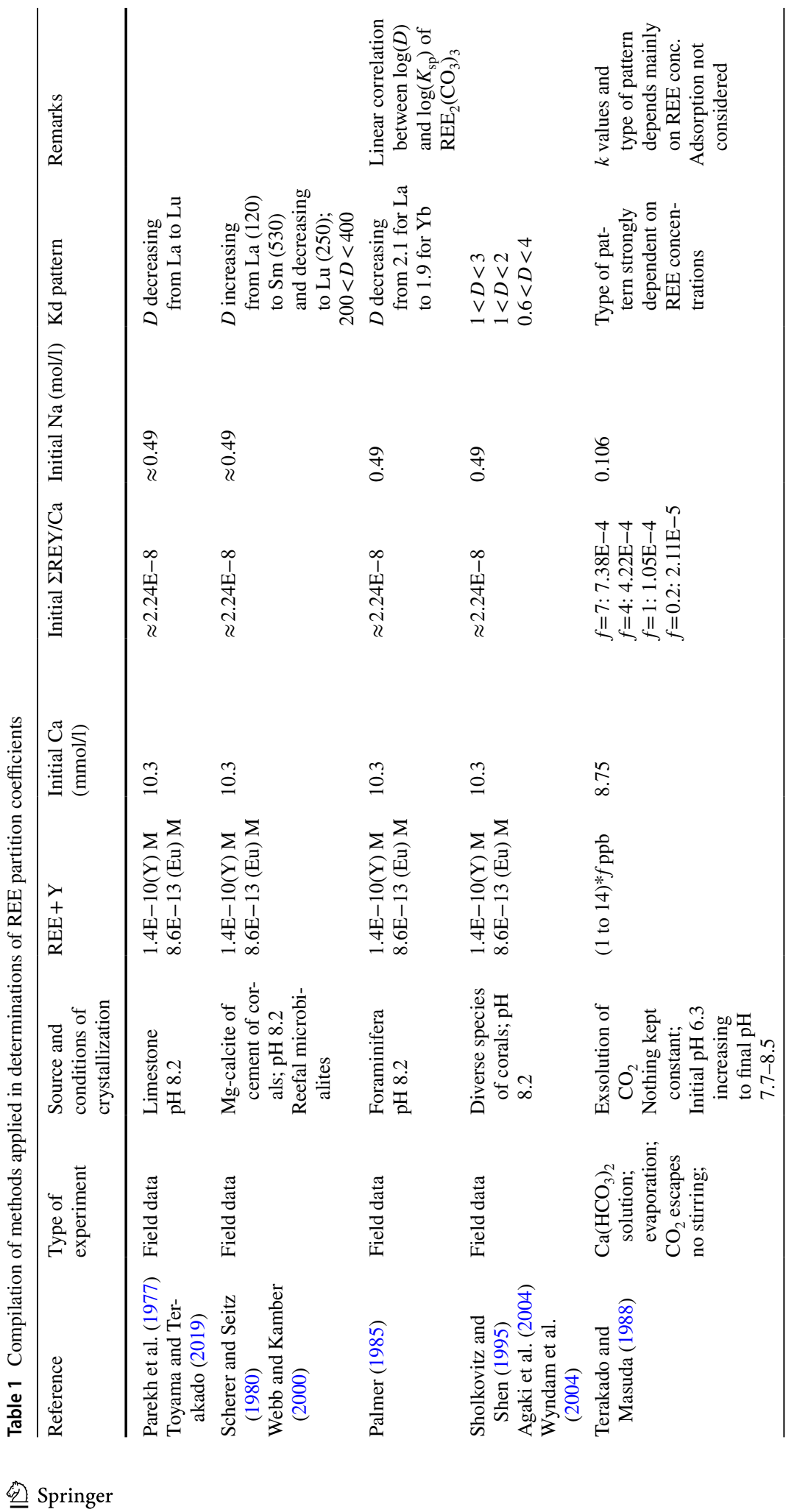




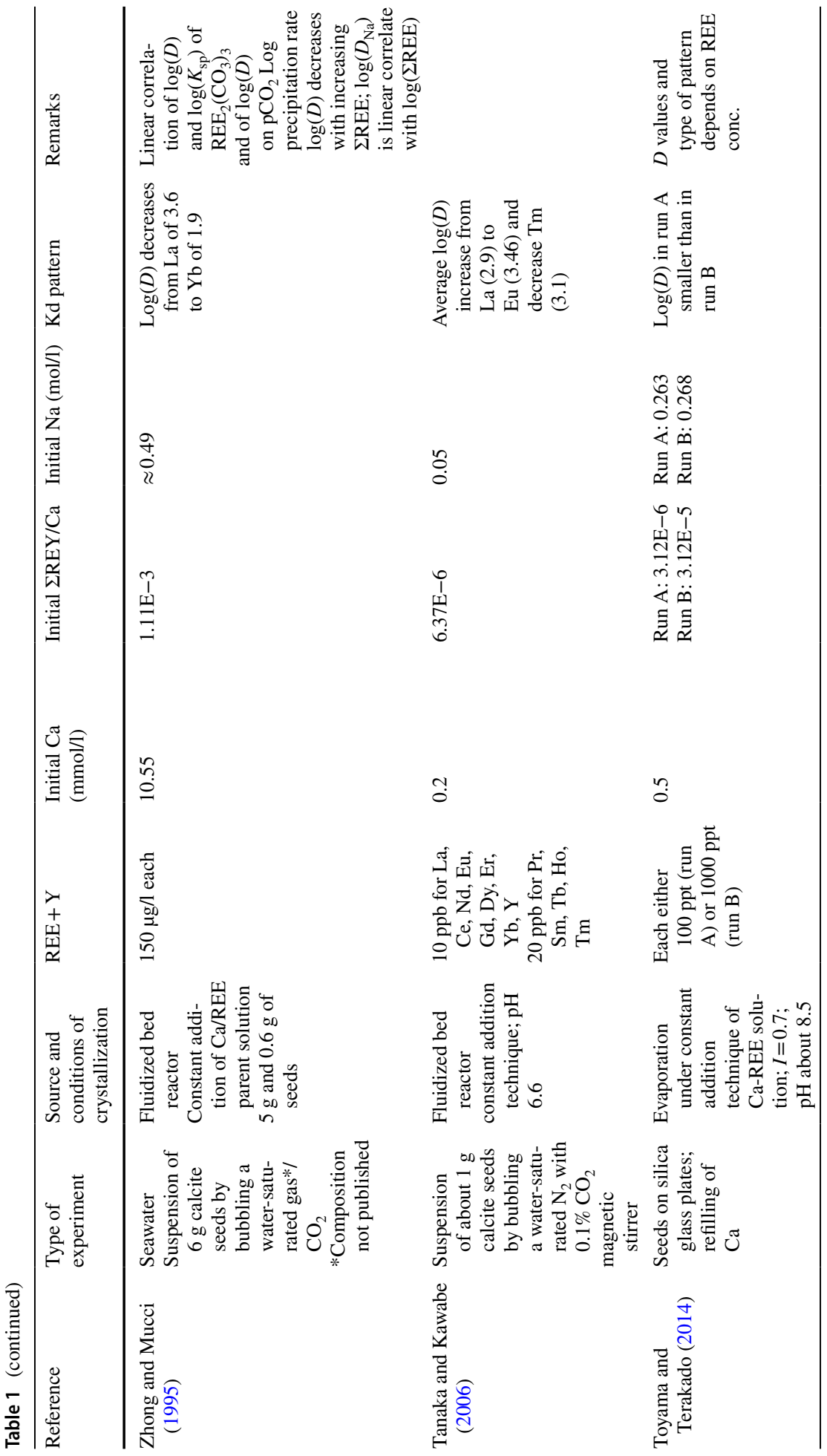




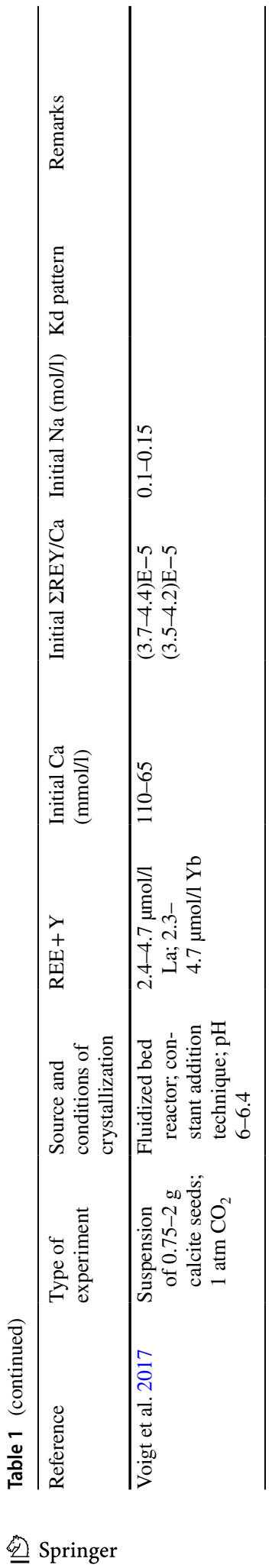


increasing $\log (\mathrm{REE})$ and $\log (\Omega-1)(\Omega=$ calcite saturation index $)$ in solution indicating an inhibiting effect of REE on the growth of calcite.

3. An evaporation technique (no stirring) under constant addition of mother solution and spike was applied by Toyama and Terakado (2014). In a pre-phase, calcite seeds were grown on movable silica glass plates. In these experiments, the initial volume of the calcite-saturated solution with $15.6 \mathrm{~g} \mathrm{NaCl} / \mathrm{l}$ and $\mathrm{REE}$ spike was maintained by refilling the reactor. The overgrowth on calcite seeds was determined by electronical weighing of the plates. The calcite growth was exclusively diffusion-controlled, i.e., [Ca] and [REE] decreased around the growing calcite crystals. Although the initial [REE] in runs $A$ and $B$ differed by a factor of 10, the final [REE] differed only by factors 2-3 (Fig. 2). Experiments $\mathrm{A} 1+\mathrm{A} 2$ and $\mathrm{B} 1+\mathrm{B} 2$ represent results after 122 and $37 \mathrm{~h}$ of calcite growth, respectively. $\log \left(D_{\mathrm{REE}}\right)$ of light REE (LREE) and heavy REE and Y (HREY) decrease in runs A-1 and (A-2) from 25-10 and 65-25, and in runs (B-1) and (B-2) from 70-40 and $95-65$, respectively.

4. $\mathrm{CO}_{2}$ exsolution from a bicarbonate solution was applied by Terakado and Masuda (1988). According to the experimental procedure, Eq. (1) is used to quantify the coefficient $k_{\mathrm{REE}}$ (Fig. 1b). The initial solution contained about $350 \mathrm{mg} / \mathrm{l} \mathrm{Ca}$. No seeds were applied. In different runs, they used a prepared spike solution of $\mathrm{REE}^{3+}$ covering a range of $f=0.2$ to 7 , where $f$ is the multiplication factor of their standard spike composition that was added to the $\mathrm{Ca}\left(\mathrm{HCO}_{3}\right)_{2}$ solution. Although the individual REE concentrations in the initial solution vary between 40 and $0.9 \mathrm{ppb}$ for $\mathrm{Nd}$ and $\mathrm{Lu}$, respectively, the derived apparent $k_{\text {REE }}$ values differ between each $f$ run but are almost similar within each $f$ run for all REE (Fig. 3a). Their $k_{\text {REE }}$ values increase from $f=0.2$ to $f=1$ and then decrease with the further increase in REE abundance.

In the above reviewed work, the values of $D_{\mathrm{REE}}$ or $k_{\mathrm{REE}}$ depend on the state of calcite saturation (Voigt et al. 2017), growth rate of calcite (Zhong and Mucci 1995; Toyama and Terakado 2014; Voigt et al. 2017), salinity (Webb and Kamber 2000), concentration of REY (Terakado and Masuda 1988; Toyama and Terakado 2014), chemical complexation

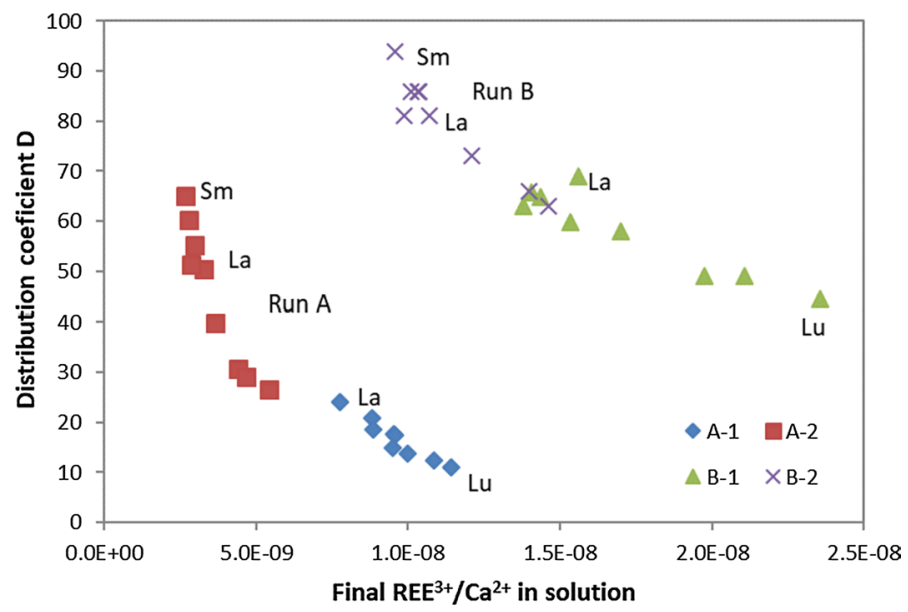

Fig. $2 D_{i}$ versus equilibrated $\mathrm{REE}_{i}$ concentrations showing different behaviors of REE in partitioning. Runs $\mathrm{A}$ and $\mathrm{B}$ show two time intervals in solutions differing in initial $\mathrm{REE}^{3+}$ concentrations by a factor of 10 . Data are taken from Toyama and Terakado (2014) 

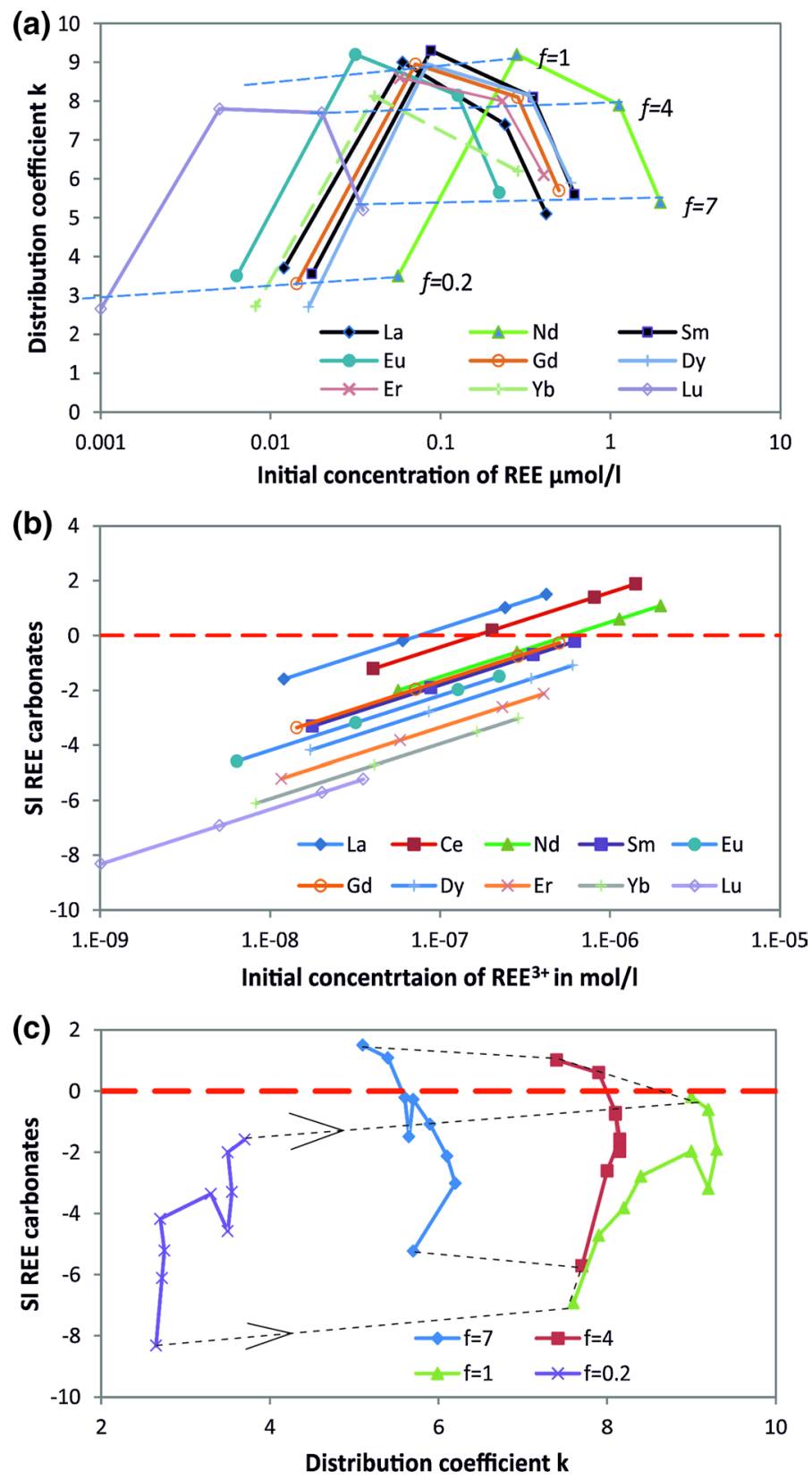

Fig. 3 Correlations of data from Terakado and Masuda's experiments (1988). a Distribution coefficients $k_{i}$ versus initial concentration of $\mathrm{REE}_{i}$. The dashed lines indicate the trends of all REE at the noted REE concentration level ( $f$-factor; for details ref. to text). These trends indicate little specific differences within the series of REE in partitioning with calcite. b Saturation index SI of REE carbonates versus initial REE concentration show that only the very light REE are supersaturated in systems with $f=7$ to 1 . c Saturation index SI of REE carbonates versus distribution coefficient $k_{i}$ show variable trends of SI with increasing $k_{i}$ values for $f=7$ to $f=1$. For $f=0.2$, the $k_{i}$ values are lower than for $f=7$. The dashed lines with arrows indicate the trend of increasing individual SI values from $f=0.2$ to $f=7$ 
(Tanaka et al. 2004; Voigt et al. 2017), temperature, $\mathrm{CO}_{2}$ partial pressure, $\mathrm{pH}$ and performance of experiments.

Irrespective of the performance of REE partitioning during calcite precipitation, there are at least three important aspects affecting REY partitioning in calcite:

- High REY concentrations induce precipitation of separate phases such as REY carbonates and hydroxides due to which REY abundance in solutions and consequently $D_{\text {REE }}$ values decrease;

- Ion exchange of $\mathrm{REY}^{3+}$ against $\mathrm{Ca}^{2+}$ form variously composed surface compounds with different kinds of charge balance;

- Chemical complexation in solutions.

The aim of this contribution is to search for a common process which could explain the wide spread of experimental partition coefficients $D_{\text {REE }}$. Are REY really homogeneously distributed in calcite or do they agglomerate to flatspread or linear surface clusters which are then overgrown by calcite? The size of such compounds may show a strong dependence of partition coefficients on the sum of REY in solution because all REE and Y behave similarly.

An outlook on REY partitioning between alcite and seawater is given because one aspect of some published studies was to gain a deeper insight into the development of REY in seawater in deep time (Shields and Webb 2004; Tanaka et al. 2004; Tanaka and Kawabe 2006; Voigt et al. 2017; Toyama and Terakado 2019). Because calcite is omnipresent in the earth's crust and preferentially precipitated from seawater, the partitioning of REY between calcite and its solution has also become a very important tool in hydrochemistry, where limestone aquifers play an important role (Johannesson et al. 1997; Möller et al. 2003; Siebert et al. 2014).

\section{Interaction of REY with Calcite}

\subsection{Exchange of $\mathrm{Mg}^{2+}$ and $\mathrm{REE}^{3+}$ Against $\mathrm{Ca}^{2+}$ in Calcite Surface}

Zhong and Mucci (1995) reported that REE concentrations immediately decreased after addition of the REE spike to the calcite suspension followed by a slow process (Fig. 4a). After this initial fast decrease in $\mathrm{La}$ and $\mathrm{Yb}$ concentration in solution (what they called: adsorption step), the further decrease of $\mathrm{Yb}$ is much less than of La with time. This difference in behavior may be due to differences in dehydration enthalpies which are less for the bigger $\mathrm{La}^{3+}$ than for the smaller $\mathrm{Yb}^{3+}$ favoring adsorption of $\mathrm{La}^{3+}$ but retarding the adsorption of $\mathrm{Yb}^{3+}$. About 25 and $40 \%$ of added $\mathrm{Yb}$ and La, respectively, is "adsorbed" causing high surface concentrations of REE. Except at thermodynamic equilibrium, the zeta potential of calcite is always negative (Moulin and Roques 2003) which promotes the adsorption $\mathrm{REY}^{3+}$ onto calcite surfaces.

A similar kinetic behavior is reported for $\mathrm{Mg}^{2+}$ exchange against $\mathrm{Ca}^{2+}$ doped by radioactive ${ }^{45} \mathrm{Ca}^{2+}$ in rhombohedral faces of calcite (Möller 1973) (Fig. 4b). With increasing $\mathrm{Mg}^{2+}$ in solution, ${ }^{45} \mathrm{Ca}^{2+}$-doped $\mathrm{Ca}^{2+}$ in the calcite surface decreases. With increasing $\mathrm{Mg}^{2+} / \mathrm{Ca}^{2+}$ in solution, the $\mathrm{Mg}^{2+} / \mathrm{Ca}^{2+}$ in the calcite surface approach distinct ratios of 1 and 3 is indicated by significant changes in slopes (Fig. 4c). These ratios resemble those of the compositions of the minerals dolomite and huntite. The ratio of 1 suggests that $\mathrm{Mg}^{2+}$ 
Fig. 4 Exchange of $\mathrm{Ca}^{2+}$ in calcite surface against foreign ions. a Drop of REE concentration when adding the spike to the calcite seed suspension (Zhong and Mucci 1995); b exchange kinetic of $\mathrm{Mg}^{2+}$ against $\mathrm{Ca}^{2+}$ in calcite surface; $\mathbf{c}$ exchange of $\mathrm{Mg}^{2+}$ against $\mathrm{Ca}^{2+}$ in calcite surface as a function of $\mathrm{Mg}^{2+} / \mathrm{Ca}^{2+}$ in solution (Möller 1973; Möller and Sastri 1973; Möller and De Lucia 2019)
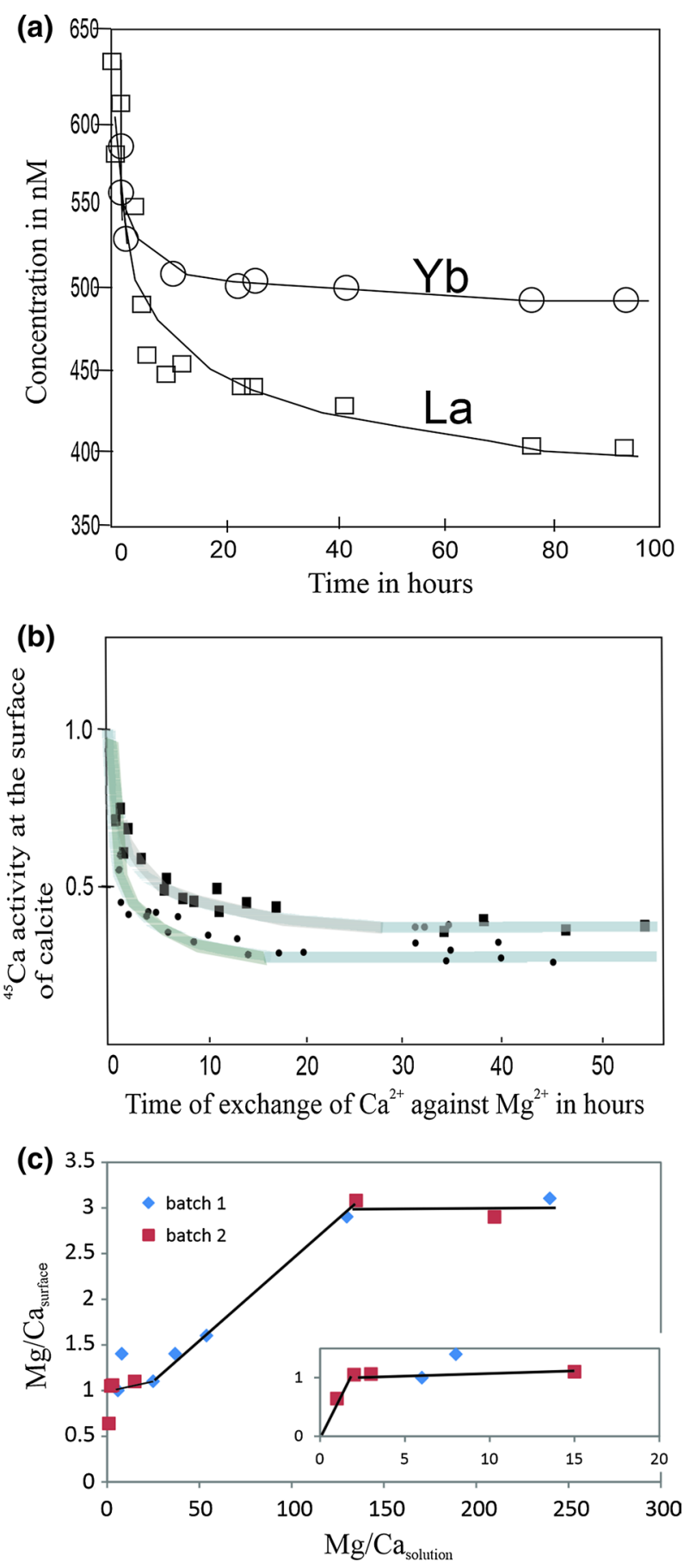


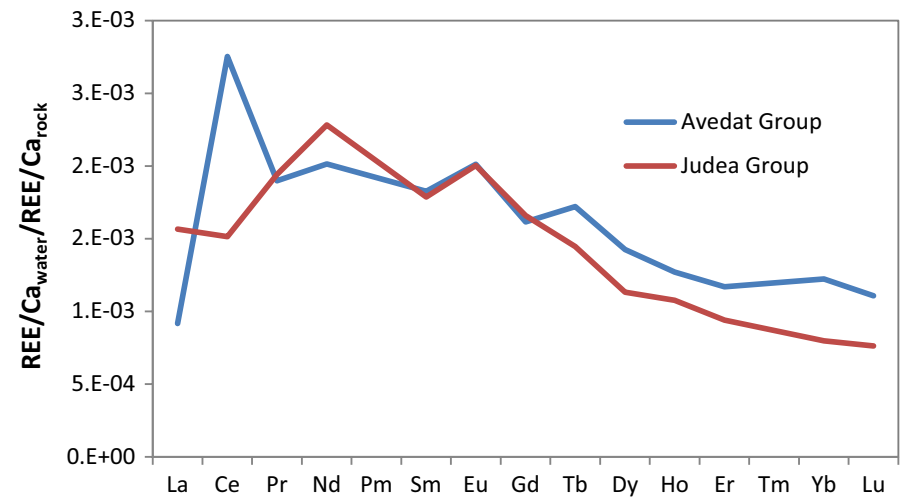

Fig. 5 Relationship between REE in groundwater and limestone aquifer rocks (Möller and Siebert 2016). Note that the given ratios are similar, although limestones are from different geological periods (Avedat Group: Eocene; Judea Group: Cenomanian). For details refer to "Appendix 1"

Table 2 Ionic radii of species discussed in the text at coordination number VI (Shannon 1976)

\begin{tabular}{lllllll}
\hline Species & $\mathrm{Na}^{+}$ & $\mathrm{Mg}^{2+}$ & $\mathrm{Ca}^{2+}$ & $\mathrm{La}^{3+}$ & $\mathrm{Y}^{3+}$ & $\mathrm{Lu}^{3+}$ \\
\hline Ionic radius nm & 0.116 & 0.7 & 0.114 & 0.117 & 0.104 & 0.100 \\
\hline
\end{tabular}

and $\mathrm{Ca}^{2+}$ are either randomly distributed or are arranged in alternating lines of $\mathrm{Ca}^{2+}$ and $\mathrm{Mg}^{2+}$. Rhombohedral faces of calcite present lines of $\mathrm{Ca}^{2+}$ and $\mathrm{CO}_{3}{ }^{2-}$. Thermodynamical estimates suggest that the arrangement of $\mathrm{Mg}^{2+}$ and $\mathrm{Ca}^{2+}$ in separate lines on rhombohedral surfaces of calcite has a minimum in free energy (Möller and Rajagopalan 1976). Using single crystals, it was shown that only about one molecular layer of calcite takes part in this type of ion exchange (Möller and Sastri 1974; Pokrovski and Sholkovitz 2001). The $\mathrm{Mg}^{2+}$ distribution in the calcite surface layer must have an effect on REY partitioning between calcite and seawater.

No specific studies of $\mathrm{REY}^{3+}$ exchange against $\mathrm{Ca}^{2+}$ in calcite surfaces are reported. Here the experience with $\mathrm{REE}^{3+}$ in groundwater may help out. The $\mathrm{REY}^{3+} / \mathrm{Ca}^{2+}$ values in groundwater from limestone aquifers are only about $2 \%$ of that in the dissolving calcite (Table 5; Fig. 5). Furthermore, $\left[\mathrm{REY}^{3+}\right] /\left[\mathrm{Ca}^{2+}\right]$ values of seamount limestones are $10^{2}-10^{4}$ times higher than their corresponding ratios in seawater (Tanaka et al. 2003; Miura et al. 2004; Toyama and Terakado 2019) indicating that during recrystallization REY from seawater are incorporated due to exchange against $\mathrm{Ca}^{2+}$. This process explains the high DREE values in limestones (Parekh et al. 1977) and disqualifies limestones as reliable reference material to derive DREE values in seawater carbonate systems.

\subsection{Charge balance}

Substitution is maximum if the size of the foreign ion is comparable with the substituted $\mathrm{Ca}^{2+}$ in calcite leading to least lattice distortion. Thus, $\mathrm{Na}^{+}$fits perfectly into $\mathrm{Ca}^{2+}$ position (Table 2). REY are either slightly larger or smaller than $\mathrm{Ca}^{2+}$. Secondly, the charge balance has to be achieved in the substitution process. There are different possibilities: associated 
substitution of $2 \mathrm{Ca}^{2+}$ by $\mathrm{REY}^{3+}+\mathrm{Na}^{+}$(Eq. 3 ) and/or $3 \mathrm{Ca}^{2+}$ by $2 \mathrm{REY}^{3+}+$ blank space in cation lattice (Eq. 4)

$$
\begin{aligned}
& 2\left\{\mathrm{Ca}^{2+}\right\}=\left\{\mathrm{REY}^{3+}+\mathrm{Na}^{+}\right\} \\
& 3\left\{\mathrm{Ca}^{2+}\right\}=\left\{2 \mathrm{REY}^{3+}+\square\right\}
\end{aligned}
$$

$\square$ blank space in the lattice.

In all reviewed experiments of partitioning of $\Sigma$ REY between calcite and solutions, the concentrations of incorporated $\mathrm{Na}^{+}$exceed by far $\mathrm{REY}^{3+}$ concentrations (Fig. 6). The excess $\mathrm{Na}^{+}$amounts are suggested to be due to occupation of $\mathrm{Na}^{+}$in crystal defects (White 1975; Busenberg and Plummer 1985; Lakstanov and Stipp 2004). Excess of $\mathrm{Na}^{+}$in the lattice may also be compensated by substitution of $\mathrm{CO}_{3}{ }^{2-}$ by $\mathrm{HCO}^{3-}$.

\subsection{Formation of REY carbonates}

Minerals of REE and $\mathrm{Y}$ are either dominated by light REE, LREE or heavy REE and Y, HREY. LREE carbonates crystallize with $8 \mathrm{H}_{2} \mathrm{O}$ (lanthanide: (La, Ce) ${ }_{2}\left(\mathrm{CO}_{3}\right)_{3} \times 8 \mathrm{H}_{2} \mathrm{O}$ ). A similar HREY compound is unknown. HREY form carbonates such as tengerite $\left(\mathrm{Y}_{2}\left(\mathrm{CO}_{3}\right)_{3} \times 3 \mathrm{H}_{2} \mathrm{O}\right)$ and lokkaite $\left(\mathrm{Ca}, \mathrm{Y}_{4}\left(\mathrm{CO}_{3}\right)_{7} \times 9 \mathrm{H}_{2} \mathrm{O}\right)$ (Cesbron 1989; Kim et al. 2018). In their experiments, Voigt et al. (2017) reported saturation states $\Omega$ of calcite and Lahydroxylbastnasite $\left(\mathrm{La}(\mathrm{OH}) \mathrm{CO}_{3}\right)$ of 1 to 11 and -1.5 to +0.6 , respectively. In any case, phases such as $\mathrm{REY}_{2}\left(\mathrm{CO}_{3}\right)_{3}, \operatorname{REY}(\mathrm{OH})_{3}$ or $\operatorname{REY}(\mathrm{OH}) \mathrm{CO}_{3}$ may play a role in partitioning of REY.

Based on the initial concentrations in experimental solutions or seawater (Table 6), the saturation indices of REY carbonates and hydroxides in each experiment and in seawater are estimated (Table 7). SI values of REE hydroxides are all negative. The precipitation of REE carbonates (Fig. 3b, c) is mostly excluded by the authors of all the above-cited studies based on $\operatorname{logarithms}$ of solubility products, $\log K_{\mathrm{sp}}$, of REE carbonates of Smith and Martell (1976) being about two orders of magnitude higher than the corresponding values of Spahiu and Bruno (1995). The initial SI of REE carbonate under conditions of the

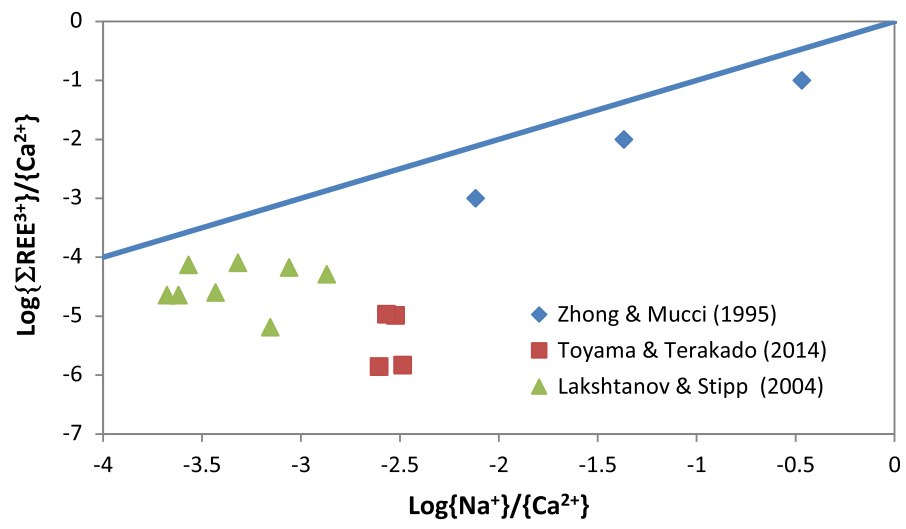

Fig. 6 Cross-plots of $\log \left(\left\{\mathrm{Na}^{+}\right\} /\left\{\mathrm{Ca}^{2+}\right\}\right)$ and $\log \left(\left\{\Sigma \mathrm{REE}^{3+}\right\} /\left\{\mathrm{Ca}^{2+}\right\}\right)$ in calcite. Note that $\left\{\mathrm{Na}^{+}\right]$exceeds by far $\left\{\Sigma \operatorname{REE}^{3+}\right\}$ 
reaction solution are checked by PHREEQC with "llnl" database (Parkhurst and Appelo 2013) after implementation of Spahiu and Bruno's data (Table 8), and results are summarized in Table 3 .

Often the less abundant REE and the very abundant $\mathrm{Y}$ are not determined in biogenic calcite and its diagenetic products. Particularly Y cannot be neglected in $\Sigma$ REY. $\{Y\}$ in calcite is approached by using $[\mathrm{Y}] /[\mathrm{Er}]$ in seawater multiplied by $[\mathrm{Er}]$ in calcite. Other absent REY are determined in a similar way. REY partitioning in marine calcite depends on the composition of local seawater which is not always given by the authors. In these cases, REE in seawater reported by Sholkovitz and Schneider (1991) is used and Y is taken from the compilation of Bruland and Lohan (2003).

Following Table 3 (Table 7), in Toyama and Terakado's (2014) and Tanaka and Kawabe's (2006) experiments, all individual SI values of REE carbonates are negative. Under the conditions of Zhong and Mucci's (1995) experiment, SI are positive for La-Sm carbonates. In Terakado and Masuda's experiments (1988), SI of light $\mathrm{REE}_{2}\left(\mathrm{CO}_{3}\right)_{3}$ the saturation indices in runs with $f=7$ and 4 are positive for $\mathrm{La}$, Ce and $\mathrm{Nd}$. For $f=1$, only Ce is positive and for $f=0.2$ SI of all carbonates are negative.

\section{Discussion}

Different from solution without $\mathrm{Mg}^{2+}$, calcite from seawater environments is subjected to ion exchange of $\mathrm{Mg}^{2+}$ against $\mathrm{Ca}^{2+}$ in their surfaces (Sect. 2.1). In seawater, the $\mathrm{Mg}^{2+} / \mathrm{Ca}^{2+}$ values are about 5 and the surface ratio of $\left\{\mathrm{Mg}^{2+}\right\} /\left\{\mathrm{Ca}^{2+}\right\}$ is about 1 (Fig. $4 \mathrm{c}$ ). Thus, calcite surfaces expose only half of their theoretical surface $\mathrm{Ca}^{2+}$ in seawater. The minimum of free energy in the surface is obtained when the distribution of $\mathrm{Ca}^{2+}$ and $\mathrm{Mg}^{2+}$ resembles that in dolomite, i.e., alternating lines of $\mathrm{Ca}^{2+}$ and $\mathrm{Mg}^{2+}$ (Möller and Rajagopalan 1976). If such a surface structure is present, REY exchange only takes place in $\mathrm{Ca}^{2+}$ lines facing the solution. Thus, partitioning of REY between calcite and natural and artificial seawater can hardly be the same as in $\mathrm{Mg}^{2+}$-free systems.

Table 3 Results of estimated saturation indices SI with respect to REE carbonates and hydroxides

\begin{tabular}{|c|c|c|c|c|}
\hline \multirow[t]{2}{*}{ Source of data } & \multicolumn{2}{|l|}{ Individual REE } & \multicolumn{2}{|l|}{ Sum of REE } \\
\hline & $\mathrm{SI}\left(\mathrm{REE}_{2}\left(\mathrm{CO}_{3}\right)_{3}\right)$ & $\mathrm{SI}\left(\mathrm{REE}_{2}(\mathrm{OH})_{3}\right)$ & $\log \left({ }^{\mathrm{a}} \mathrm{SREE}^{3+}\right)$ & $\mathrm{SI}\left(\mathrm{SREE}_{2}\left(\mathrm{CO}_{3}\right)_{3}\right)$ \\
\hline \multicolumn{5}{|l|}{ Terakado and Masuda } \\
\hline $\mathrm{f}=7$ & Positive (La-Nd) & Negative & -7.08 & 2.51 \\
\hline$f=4$ & Positive (La-Nd) & Negative & -7.33 & 2.02 \\
\hline$f=1$ & Positive (Ce) & Negative & -7.93 & 0.82 \\
\hline $\mathrm{f}=0.2$ & Negative & Negative & -8.63 & -0.58 \\
\hline Zhong and Mucci & Positive (La-Sm) & Negative & -7.13 & 2.77 \\
\hline Tanaka and Kawabe & Negative & Negative & -7.41 & -2.00 \\
\hline \multicolumn{5}{|l|}{ Toyama and Terakado } \\
\hline Run A & Negative & Negative & -10.84 & -3.61 \\
\hline Run B & Negative & Negative & -9.84 & -1.05 \\
\hline $\begin{array}{l}\text { Sholkeviz and Schnei- } \\
\text { der (sea water) }\end{array}$ & Negative & Negative & -11.95 & -7.46 \\
\hline
\end{tabular}

Estimates are made for each $\mathrm{REE}^{3+}$ and the $\Sigma \mathrm{REE}^{3+}$ species 


\subsection{Partitioning of individual REE}

Except $\mathrm{Ce}$, which often displays anomalous behavior because of oxidation to $\mathrm{Ce}(\mathrm{IV})$, REE seemingly behave alike in partitioning with respect to calcite (Terakado and Masuda 1988), irrespective of their actual concentrations in the fluid phase (Fig. 3a). Although the concentrations of $\mathrm{La}$ and $\mathrm{Nd}$ differ from Eu by factors of about 30 in the initial solution of these experiments, their derived $k_{\text {REE }}$ values are comparable for all REE in each experiment defined by $f$. The $f$-dependent changes of REY partitioning give evidence of different processes. Starting with the highest concentration of REE $(f=7), k_{\text {REE }}$ values increase with decreasing REE concentration $(f=4$ and 1$)$ achieving maximum at about $f=1$. This increase suggests that decreasing density of adsorbed $\mathrm{REE}^{3+}$ avoids nucleation of REY carbonates being separated from the surface. Indeed, LREE are supersaturated with respect to REE carbonates (Fig. $3 \mathrm{~b}, \mathrm{c}$ ). The lowest $k_{\mathrm{REE}}$ values are obtained at $f=0.2$. Contrasting these results are those of Toyama and Terakado (2014) in which the initial differences of REE concentrations by a factor of 10 are not reflected in $D_{\text {REE }}$ values (Fig. 2). Although the input of REE in each run was constant over time, the resultant $D_{\mathrm{REE}}$ values decreased from LREE to HREE, i.e., significant fractionation of $\mathrm{REE}^{3+}$ occurred. The fractionation of REE is similar in both runs. La does not show the highest coefficients in runs A1 and B1. Because $D_{\text {REE }}$ values depend on the degree of calcite saturation (Terakado and Masuda 1988; Voigt et al. 2017), the enforced growth of calcite seems to override the process of equilibration of REE between solution and adsorption onto surfaces and place changes across the surfaces until the exchange with $\mathrm{Ca}^{2+}$ occurs.

The values of $\left\{\mathrm{REE}_{i}\right\} /\left\{\mathrm{Ca}^{2+}\right\}$ are derived from reported $D_{\mathrm{REE}, i}$ values multiplied by corresponding $\left[\mathrm{REE}_{i}\right] /[\mathrm{Ca}]$ values according to Eq. (2). In the double logarithmic plot of $\left\{\mathrm{REE}_{i}\right\} /\{\mathrm{Ca}\}$ versus $[\mathrm{REE}] /[\mathrm{Ca}]$ two possibly linear, subparallel relationships evolve (Fig. 7). The solid line (Eq. 5a) characterizes $\mathrm{Mg}^{2+}$-free systems based on Toyama and Terakado's (2014) and Voigt's et al. (2017) results. The average of eight experiments of Tanaka and Kawabe (2006) does not fit Eq. (5a). The dashed line (Eq. 6a) is based on results of $\mathrm{Mg}^{2+}$-dominated solutions such as seawater (Zhong and Mucci 1995; Parekh et al. 1977; Scherer and Seitz 1980; Palmer 1985; Toyama and Terakado 2019).

Using the dissolved species $\mathrm{REY}^{3+}$ and $\mathrm{Ca}^{2+}$ instead of concentrations of REY and $\mathrm{Ca}$ correlations (7a) and (8a) evolve (Fig. 7b). The overall fit of all reported values including the average of Tanaka and Kawabe (2006) is better than in Fig. 7a. Contrasting the total concentration of individual $\mathrm{REE}_{i}$, the dissolved $\mathrm{REE}_{i}^{3+}$ species yield trend lines that seem to merge at low REY concentrations with the trend line representing partitioning between calcite and seawater (Fig. 7b).

\subsection{Partition of the Entirety of REY}

Although it is known that REY substitute each other in minerals, it is still common practice to consider the individual $\mathrm{REE}^{3+}$ and not the entirety of all REY as one "species" in partitioning between calcite and solutions. For instance, the individual $\log \left(D_{\mathrm{La}}\right)$ and $\log \left(D_{\mathrm{Yb}}\right)$ are slightly higher than those derived from mixtures of both elements (Voigt et al. 2017).

Equations (9a) and (12a) in Fig. 7c and d describe the correlation of $\{\Sigma \mathrm{REY}\} /\{\mathrm{Ca}\}$ and either $[\Sigma \mathrm{REY}] /[\mathrm{Ca}]$ or $\left[\Sigma \mathrm{REY}_{i}^{3+}\right] /\left[\mathrm{Ca}^{2+}\right]$, respectively. Note that Eqs. (9a) and (10a) resemble Eqs. (5a) and (6a), and Eqs. (11a) and (12a) resemble Eqs. (7a) and (8a). There 


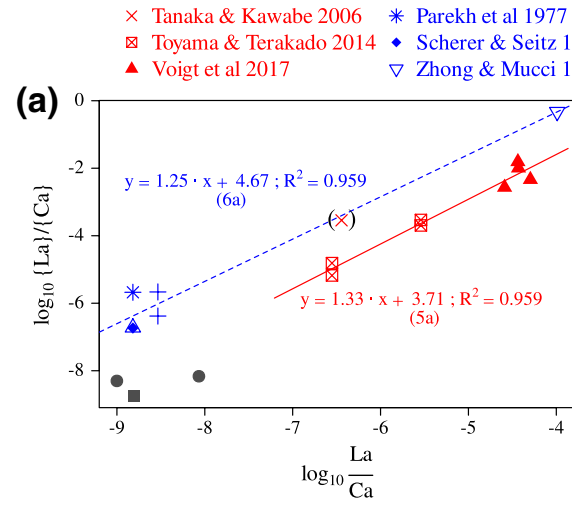

$$
\begin{array}{ll}
+ \text { Toyama \& Terakado } 2019 & \bullet \text { Agaki et al } 2004 \\
\triangle \text { Palmer } 1985 & \text { Sholkovitz \& Shen } 1995
\end{array}
$$

(b)
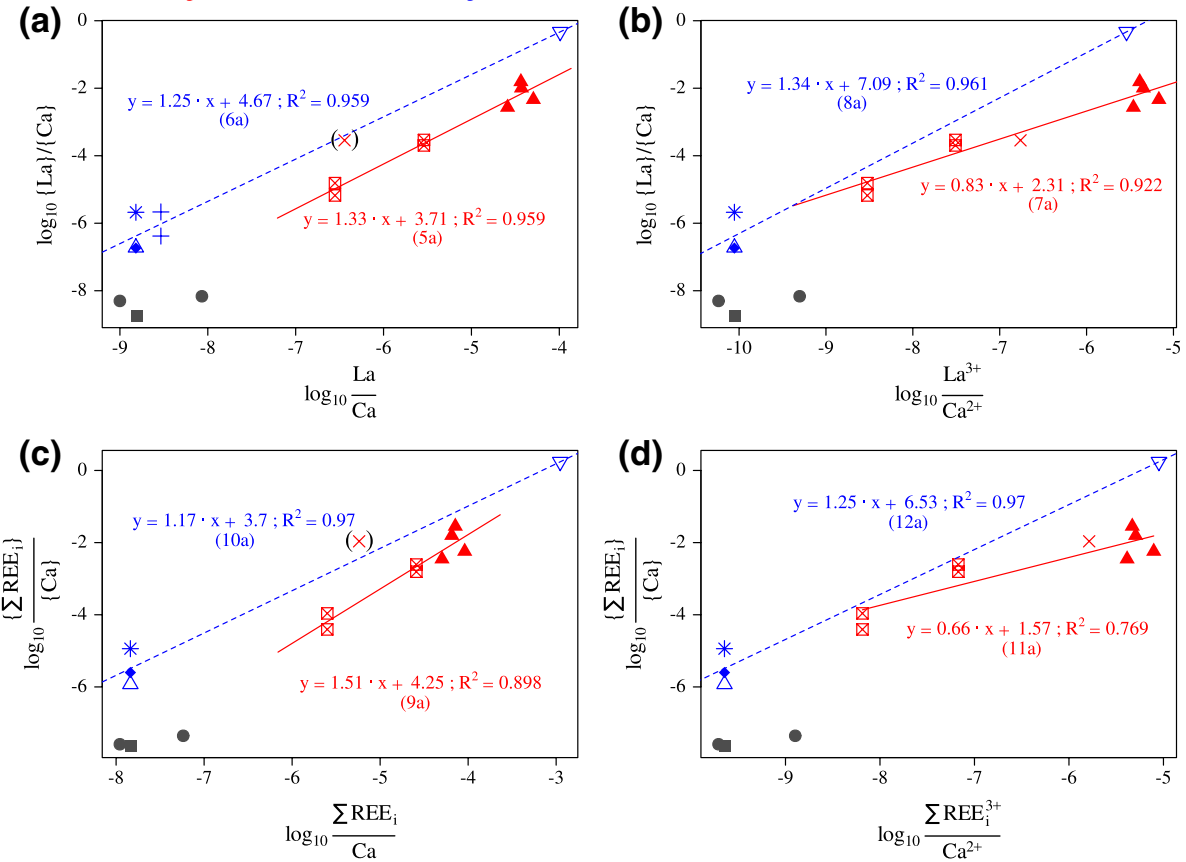

Fig. 7 Correlations between $\log \left(\left\{\mathrm{La}^{3+}\right\} /\left\{\mathrm{Ca}^{2+}\right\}\right)$ in calcite as functions of either $\left[\mathrm{REY}{ }_{i}\right] /[\mathrm{Ca}]$ or $\left[\mathrm{REY}_{i}^{3+}\right] /$ $\left[\mathrm{Ca}^{2+}\right]$ and between $\log \left(\left\{\Sigma \mathrm{REY}{ }_{i}\right\} /\{\mathrm{Ca}\}\right)$ as functions of either $[\Sigma \mathrm{REY}] /[\mathrm{Ca}]$ or $\left[\Sigma \mathrm{REY}_{i}^{3+}\right] /\left[\mathrm{Ca}^{2+}\right]$. Note that the slopes in the double logarithmic plots of $\mathbf{a}, \mathbf{c}$, or $\mathbf{b}, \mathbf{d}$ are nearly the same. Any homogeneous partitioning should be indicated by a slope of $n=1$

is, however, a significant difference in using either total concentrations or dissolved species. Using the dissolved species, the resulting regression lines seemingly merge at very low concentrations of REY. The different slopes in Fig. 7 give evidence of the influence of $\mathrm{Mg}^{2+}$ on the incorporation of REY. The pre-factors are significantly smaller in the absence of $\mathrm{Mg}^{2+}$ than in its presence.

\subsection{Partition Coefficients as Functions of REY Concentrations in Solution}

Dividing Eqs. (5a)-(12a) by the correspondent ratios of either REY and Ca or REY ${ }^{3+}$ and $\mathrm{Ca}^{2+}$ in solution, the REY partition coefficients are obtained as functions of their corresponding ratios [Eqs. (5b)-(12b) in Table 4]. The resultant $D_{\text {REY }}$ values as function of the ratios of REY and Ca yield subparallel trends for $D_{\text {REY }}$ values in seawater and in $\mathrm{Mg}^{2+}$-free solutions (Fig. 8a). A different result is obtained for $D_{\mathrm{REY}}$ values, if the tervalent species in solution are considered. $D_{\mathrm{REY}}$ in seawater increases with REY, whereas $D_{\mathrm{REY}}$ in $\mathrm{Mg}^{2+}$-free solution decreases with increasing REY (Fig. 8b). 
Table 4 Compilation of regression lines in Fig. 7 and the derived trend lines of REY partition coefficients between, calcite and ambient solutions

\begin{tabular}{|c|c|c|c|c|}
\hline \multicolumn{5}{|c|}{ Without $\mathrm{Mg}^{2+}$ in solution } \\
\hline $5 \mathrm{a}$ & $\left.\{\mathrm{La}\} /\{\mathrm{Ca}\}=10^{3.71}(\mathrm{La}] /[\mathrm{Ca}]\right)^{1.33}$ & $5 \mathrm{~b}$ & $D_{\mathrm{La}}=10^{3.71}([\mathrm{La}] /[\mathrm{Ca}])^{0.33}$ & Figure $7 \mathrm{a}$ \\
\hline $7 a$ & $\{\mathrm{La}\} /\{\mathrm{Ca}\}=10^{2.31}\left(\left[\mathrm{La}^{3+}\right] /\left[\mathrm{Ca}^{2+}\right]\right)^{0.83}$ & $7 \mathrm{~b}$ & $D_{\mathrm{La}}=10^{2.31}\left(\left[\mathrm{La}^{3+}\right] /\left[\mathrm{Ca}^{2+}\right]\right)^{-0.17}$ & Figure $7 b$ \\
\hline $9 \mathrm{a}$ & $\left\{\Sigma \mathrm{REY}^{3+}\right\} /\left\{\mathrm{Ca}^{2+}\right\}=10^{4.25}\left(\left[\Sigma \mathrm{REY}_{i}\right] /[\mathrm{Ca}]\right)^{1.51}$ & $9 b$ & $D_{\mathrm{REY}}=10^{4.25}\left(\left[\Sigma \mathrm{REY}_{i}\right] /[\mathrm{Ca}]\right)^{0.51}$ & Figure $7 \mathrm{a}$ \\
\hline $11 \mathrm{a}$ & $\left.\left\{\Sigma \mathrm{REY}^{3+}\right\} / \mathrm{Ca}^{2+}\right\}=10^{1.57}\left(\left[\Sigma \mathrm{REY}_{i}^{3+}\right] /\left[\mathrm{Ca}^{2+}\right]\right)^{0.66}$ & $11 b$ & $D_{\text {¿REY }}=10^{1.57}\left(\left[\Sigma \mathrm{REY}_{i}^{3+}\right] /\left[\mathrm{Ca}^{2+}\right]\right)^{-0.34}$ & Figure $7 \mathrm{~b}$ \\
\hline \multicolumn{5}{|c|}{ With $\mathrm{Mg}^{2+}$ in solution } \\
\hline $6 a$ & $\{\mathrm{La}\} /\{\mathrm{Ca}\}=10^{4.67}([\mathrm{La}] /[\mathrm{Ca}])^{1.25}$ & $6 \mathrm{~b}$ & $D_{\mathrm{La}}=10^{4.67}([\mathrm{La}] /[\mathrm{Ca}])^{0.25}$ & Figure $7 \mathrm{a}$ \\
\hline $8 \mathrm{a}$ & $\{\mathrm{La}\} /\{\mathrm{Ca}\}=10^{7.09}\left(\left[\mathrm{La}^{3+}\right] /\left[\mathrm{Ca}^{2+}\right]\right)^{1.34}$ & $8 b$ & $D_{\mathrm{La}}=10^{7.709}\left(\left[\mathrm{La}^{3+}\right] /\left[\mathrm{Ca}^{2+}\right]\right)^{0.34}$ & Figure $7 \mathrm{~b}$ \\
\hline 10a & $\left.\left\{\Sigma \mathrm{REY}^{3+}\right\} /\left\{\mathrm{Ca}^{2+}\right\}=10^{3.7}[\Sigma \mathrm{REY}] /[\mathrm{Ca}]\right)^{1.17}$ & $10 \mathrm{~b}$ & $D_{\mathrm{REY}}=10^{3.7}([\Sigma \mathrm{REY}] /[\mathrm{Ca}])^{0.17}$ & Figure $7 \mathrm{a}$ \\
\hline $12 \mathrm{a}$ & $\left\{\Sigma \mathrm{REY}^{3+}\right\} /\left\{\mathrm{Ca}^{2+}\right\}=10^{7.39}\left(\left[\Sigma \mathrm{REY}^{3+}\right] /\left[\mathrm{Ca}^{2+}\right]\right)^{1.27}$ & $12 b$ & $D_{\mathrm{SREY}}=10^{7.39}\left(\left[\Sigma \mathrm{REY}^{3+}\right] /\left[\mathrm{Ca}^{2+}\right]\right)^{0.27}$ & Figure $7 \mathrm{~b}$ \\
\hline
\end{tabular}
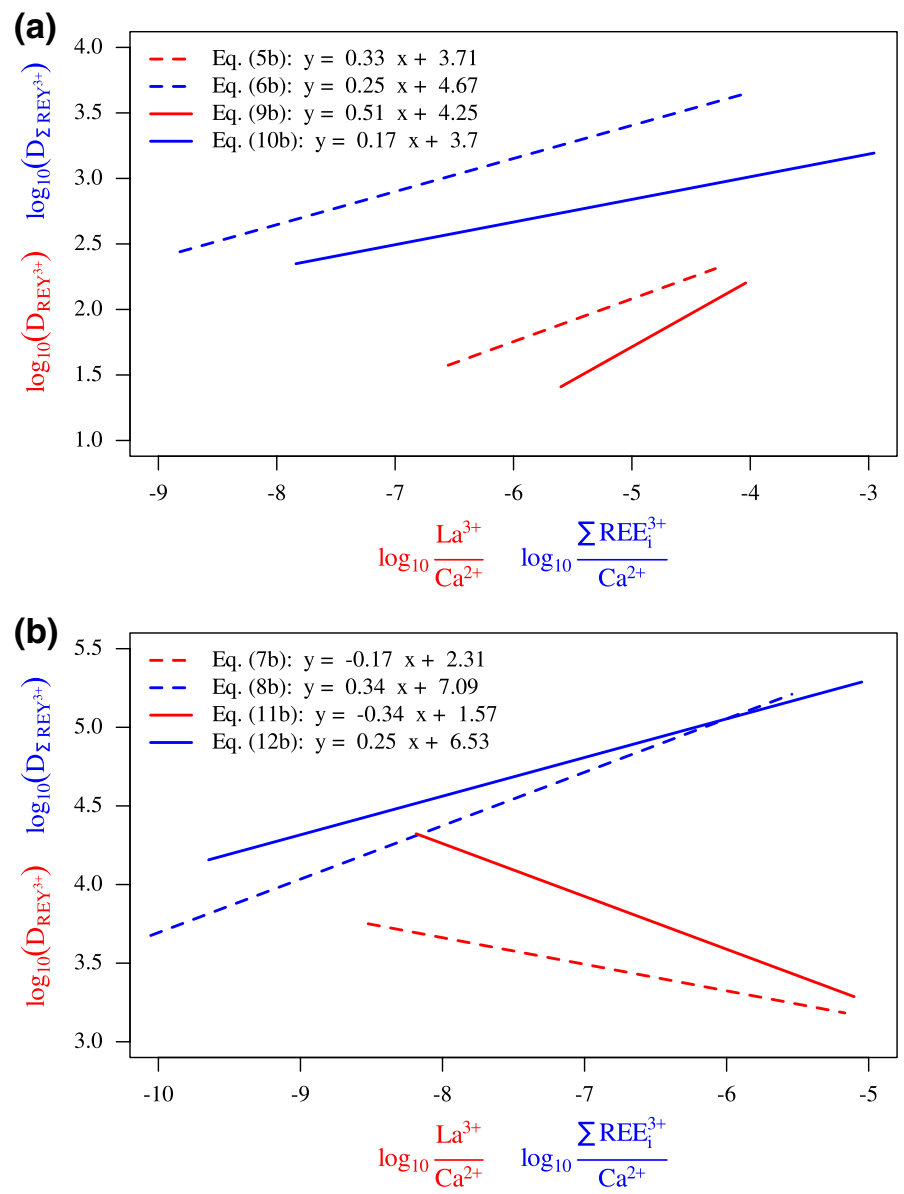

Fig. 8 Correlations of $\log \left(D_{\mathrm{REY}}\right)$ and $\log \left(D_{\mathrm{La}}\right)$ and REY in aqueous phases. The corresponding functions of $D$ are taken from Table 4 . Note the correspondence of $\log D$ when related to either $\Sigma \mathrm{REY}^{3+} \mathrm{or} \mathrm{La}^{3+}$, whereas in $\mathrm{Mg}^{2+}$-free systems different trend lines evolve 
Which is the best representation of the behavior of REY in partitioning? The plots of tervalent dissolved species of $\mathrm{REY}_{i}^{3+}$ are more reliable because Tanaka and Kawabe's data plot along the regression lines [Eqs. (7a) and (11a) (Fig. 7b and 11b)]. Equation (7a) is seemingly the best representation in terms of linear regression line, whereas Eq. (11a) could also be fitted by a curve.

\subsection{REE partitioning in calcite and aragonite in seawater}

The evaluation of $D_{\text {REY }}$ values in marine carbonates has to consider that, independently of actually measured REE species, all REY are present in calcite.

The marine calcite and cleaned limestones cluster at $\log \{\mathrm{La}\} /\{\mathrm{Ca}\}$ of about -5.5 to -7 when plotted either against $\mathrm{REY}_{i}$ or $\Sigma \mathrm{REY}_{i}$. Limestones and cements of corals are of diagenetic origin, i.e., recrystallization under exchange of seawater. Microbialites show enhanced $\mathrm{REY}_{i}$ taken up during their recrystallization (Scherer and Seitz 1980; Wyndam et al. 2004). The foraminifera of Palmer are very high in REY which may be caused by exchange with their highly enriched REY of their coatings.

For comparison, aragonites from corals plot below $\log \{\mathrm{La}\} /\{\mathrm{Ca}\}=-7.5$. The corals from Bermuda reefs (Sholkovitz and Shen 1995), the Great Barrier Reef of Australia (Wyndam et al. 2004; Webb and Kamber 2000) and various coral species from Okinawa, Japan (Agaki et al. 2004), show species-dependent $D_{\mathrm{REY}}$ between 0.6 and 5. Their growth is mediated by biogenic processes with insignificant fractionation of REY. For instance, $\{\mathrm{REE}\} /\{\mathrm{Ca}\}$ of modern corals resembles $[\mathrm{REE}] /[\mathrm{Ca}]$ in seawater (Sholkovitz and Shen 1995; Agaki et al. 2004; Wyndam et al. 2004).

\subsection{Surface Processes Influencing Partitioning of REY}

The regression lines of the marine calcite and the results of Zhong and Mucci in artificial seawater reveal enhanced data of $\log \left\{\mathrm{La}^{3+}\right\} /\left\{\mathrm{Ca}^{2+}\right\}$ compared with experimental results in the absence of $\mathrm{Mg}^{2+}$ (Figs. 7, 8). The slopes of these regression lines exceed unity (Fig. 7) or zero (Fig. 8), which is unexpected for homogeneous partitioning after Eq. (2). Based on total concentrations, the resulting partition coefficients increase with either increasing $\left[\mathrm{REY}_{i}^{3+}\right] /\left[\mathrm{Ca}^{2+}\right]$ and $\left[\Sigma \mathrm{REY}_{i}^{3+}\right] /\left[\mathrm{Ca}^{2+}\right]$ in solution. Contrasting this result, the slope in $\mathrm{Mg}^{2+}$-free systems is less than unity, when using dissolved species (Fig. 8b). Thus, the question arises, why does $\left\{\mathrm{REY}_{i}\right\} /\{\mathrm{Ca}\}$ and $D_{\mathrm{REY}}$ increase in the presence of $\mathrm{Mg}^{2+}$-bearing solution and why does the ratio decrease in the absence of $\mathrm{Mg}^{2+}$ in Fig. $8 \mathrm{~b}$, whereas in both systems $D_{\mathrm{REY}}$ increases when related to increasing total concentrations (Fig. 8a)?

In $\mathrm{Mg}^{2+}$-free solutions, the first step is adsorption of REY onto the surface of calcite. Moving across the surface, the adsorbed REY may come across already exchanged REY ${ }^{3+}$ for $\mathrm{Ca}^{2+}$ in the surface layer. Due to distortion of the anion layer, its exchange for a neighboring $\mathrm{Ca}^{2+}$ is favored, hence a linear structure of cluster starts growing as shown for $\mathrm{Mg}^{2+}$ exchange in calcite surfaces (Möller and Rajagopalan 1976). With the growth of calcite, large amounts of $\mathrm{Ca}^{2+}$ have to be adsorbed and some of them may replace REY in lattice sites of calcite surface. Thus, the $\{R E Y\} /\{\mathrm{Ca}\}$ value in the surface layer that will be overgrown by calcite loses some $\mathrm{REY}_{i}$.

In the presence of $\mathrm{Mg}^{2+}, \mathrm{REY}^{3+}$ exchange against $\mathrm{Ca}^{2+}$ only occurs in remaining $\mathrm{Ca}^{2+}$ lines, which, together with associated $\mathrm{CO}_{3}^{2-}$, dominate about $50 \%$ of the calcite surface in 


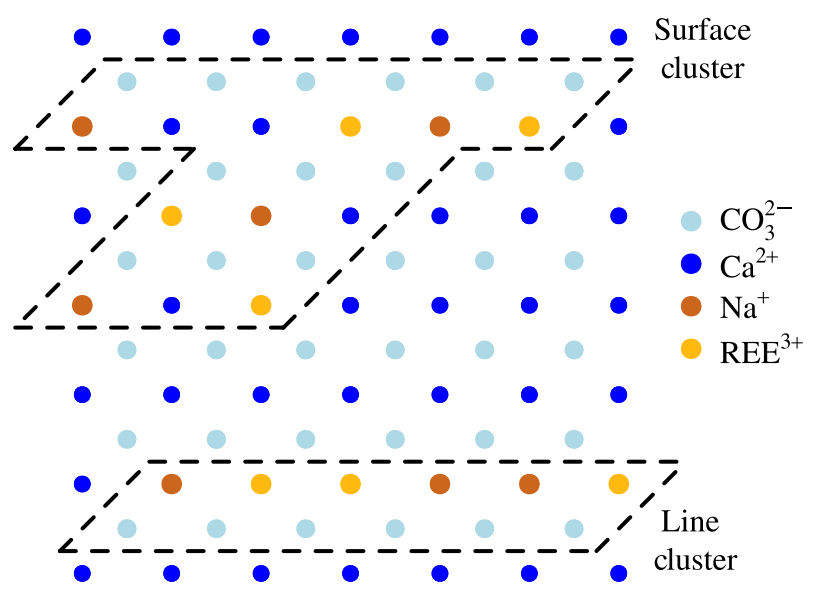

Fig. 9 Schematic arrangement of $\mathrm{Ca}^{2+}, \mathrm{Na}^{+}, \mathrm{REY}^{3+}$ in either line or surface clusters in a rhombohedral cleavage surface of calcite

seawater. The exchange of REY against $\mathrm{Mg}^{2+}$ is unlikely because of the great difference in ionic ratios (Table 2). Along with growth of calcite, almost all $\mathrm{Mg}^{2+}$ has to be substituted by $\mathrm{Ca}^{2+}$, a process during which also $\mathrm{REY}^{3+}$ may be incorporated particularly because of their enhanced charge. Compared to a homogeneous distribution of REY on calcite surface in $\mathrm{Mg}^{2+}$-free solution, $\mathrm{REY}$ are enriched during growth of calcite. Each line or flatspread surface cluster consists of $n$ lines presenting 2 or $2 n$ sites for ongoing ion exchange, respectively (Fig. 9). The tendency to form surface clusters depends on the change of reaction free energy in the surface of calcite. Loss of free energy is higher for $\mathrm{HREY}^{3+}$ than for $\mathrm{LREE}^{3+}$ because the former are smaller than $\mathrm{Ca}^{2+}$ ions (Table 2). Once clusters formed, the enthalpy for removing a REE from a cluster is enhanced compared to removal of an isolated $\mathrm{REY}^{3+}$. These clusters seemingly build at REY concentrations in solutions much below the solubility products of REY carbonates. $\mathrm{Na}^{+}$and $\mathrm{REY}^{3+}$ are probably placed near to each other. These assemblages correspond to REY incorporation in either line or surface clusters of the average composition of $\left\{\mathrm{REY}-\mathrm{Na}-\left(\mathrm{CO}_{3}\right)_{2}\right\}$ as suggested by Tanaka and Kawabe (2006). Voigt et al. (2017) suggested $\left\{\mathrm{REY}(\mathrm{OH})\left(\mathrm{CO}_{3}\right)_{2}\right\}$. Any homogeneous distribution is only achieved when the concentration of $\mathrm{REY}^{3+}$ in the calcite surface is extremely low keeping them clearly separated during growth of calcite. Although the saturation index for $\Sigma$ REY carbonates in seawater is - 7.5 (Table 7), small REY clusters may still form (Fig. 9). The formation of clusters is the source of high enrichment of REY in growing calcite.

The scatter in Fig. 7 may be caused by different processes: (1) The natural material was not clean enough and thus inappropriate to be used for determination of $D_{\mathrm{REY}}$ coefficients and/or (2) the biogenic-sourced calcite differs from inorganically precipitated low magnesian calcite by enhanced $\mathrm{REY}^{3+}$ abundances in this material and this enhancement can be species-dependent. REE $+\mathrm{Y}$ in seawater do not form $\mathrm{REY}_{2}\left(\mathrm{CO}_{3}\right)_{3}$, but the less soluble phosphates may be precipitated (Spahiu and Bruno 1995) and may be enclosed in growing calcite. For instance, $\log \left(K_{\mathrm{sp}}\right)$ of $\mathrm{LaPO}_{4}$ is -40.01 , i.e., much lower than for La carbonate. REY-phosphate clusters may also be present in biogenic carbonates. Microbialites show enhanced REY taken up during their recrystallization (Scherer and Seitz 1980; Wyndam et al. 2004). The foraminifera of Palmer are very high in REY which may be caused by exchange with their highly enriched REY of their coatings. 
Homogeneous distribution of $\mathrm{REY}^{3+}$ in calcite surfaces is only possible under extremely low $\left[\Sigma \mathrm{REY}^{3+}\right] /\left[\mathrm{Ca}^{2+}\right]$ in aqueous systems and would require much lower concentrations than $\Sigma \mathrm{REY}^{3+}$ in seawater.

\section{Conclusions}

A critical re-evaluation of REY partitioning coefficients with respect to calcite reveals that the reported, wide-spread experimental $D_{\mathrm{REY}}$ values reflect that two processes have been overlooked.

In the absence of $\mathrm{Mg}^{2+}$, the whole calcite surface is accessible for $\mathrm{REY}^{3+}$ exchange against $\mathrm{Ca}^{2+}$. The result of this exchange is reduced under the influence of continuing overgrowth of the next calcite layer. This leads to sub-proportional correlation of REY between the aqueous phase and the bulk of calcite.

The $\mathrm{Mg}^{2+}$ ion exchange against $\mathrm{Ca}^{2+}$ in calcite surface layers interfere with the exchange of $\mathrm{REY}^{3+}$ against $\mathrm{Ca}^{2+}$. All rhombohedral faces of calcite show a composition of $\mathrm{Mg}^{2+} / \mathrm{Ca}^{2+}$ of about 1 in seawater. Thus, only half of the theoretical numbers of $\mathrm{Ca}^{2+}$ ions are accessible for REY exchange against $\mathrm{Ca}^{2+}$. REY are slightly concentrated in these remaining $\mathrm{Ca}^{2+}$ lines. The growth of calcite requests that most of the $\mathrm{Mg}^{2+}$ has to be removed and substituted by $\mathrm{Ca}^{2+}$ and $\mathrm{REY}^{3+}$. $\mathrm{REY}^{3+}$ may be enriched because of their enhanced charge. These processes together may explain any over-proportional relationship of REY/Ca between the bulk of calcite and solution. Because REY partitioning in limestone is thought to be a key in understanding REY development in seawater, the effect of the presence of $\mathrm{Mg}^{2+}$ has to be considered.

Two different trend lines evolve: one for $\mathrm{Mg}^{2+}$ free systems and the other for artificial and natural seawater. Because of subtle exchange processes, the sum of all REY evidence that REY/Ca in solution are not linearly correlated with $\{\Sigma \mathrm{REY}\} /\{\mathrm{Ca}\}$ in the bulk of calcite as expected by the Henderson and Kracek rule. It seems that REY form clusters in the surface of growing calcite, even if the solubility product of REY carbonates is not reached.

Acknowledgements Open Access funding provided by Projekt DEAL. The authors greatly acknowledged the comments of two anonymous reviewers which encouraged us to improve the manuscript.

Open Access This article is licensed under a Creative Commons Attribution 4.0 International License, which permits use, sharing, adaptation, distribution and reproduction in any medium or format, as long as you give appropriate credit to the original author(s) and the source, provide a link to the Creative Commons licence, and indicate if changes were made. The images or other third party material in this article are included in the article's Creative Commons licence, unless indicated otherwise in a credit line to the material. If material is not included in the article's Creative Commons licence and your intended use is not permitted by statutory regulation or exceeds the permitted use, you will need to obtain permission directly from the copyright holder. To view a copy of this licence, visit http://creativecommons.org/licenses/by/4.0/.

\section{Appendix 1: SI of Individual and the Entirety of REE Carbonates}

Behavior of $\mathrm{REY}^{3+}$ in dissolution of limestone in groundwater. Only a few \%o of released $\mathrm{REY}^{3+}$ remain in solution (Table 5). 


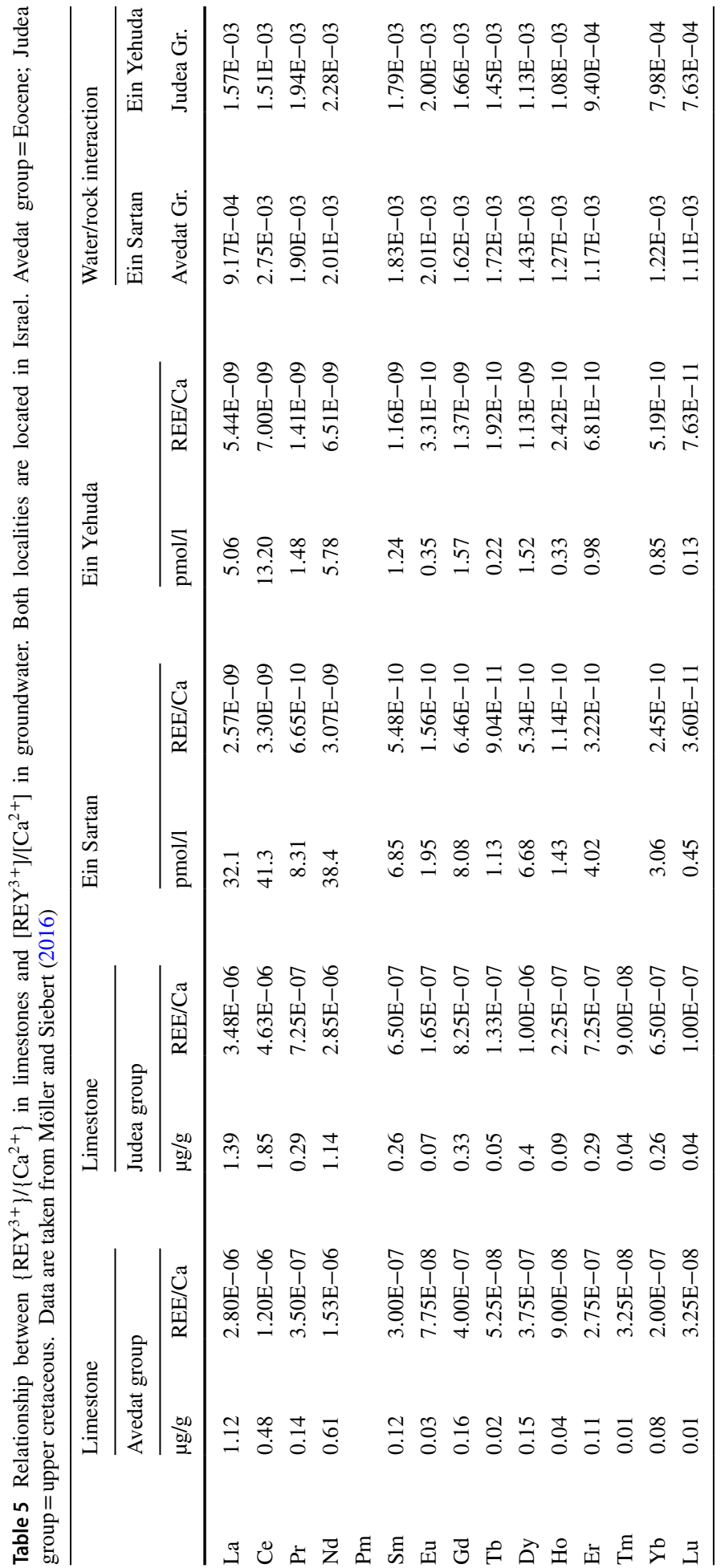




\section{Appendix 2}

Compilation of the initial concentrations in experimental solutions is compiled in Table 6.

The logarithms of individual activities, $\log \left({ }^{\mathrm{a}} \mathrm{REE}^{3+}\right), \log \left({ }^{\mathrm{a}} \mathrm{CO}_{3}{ }^{2-}\right)$ and $\log \left({ }^{\mathrm{a}} \mathrm{OH}^{-}\right)$are estimated using PHREEQC with "lln" database (Table 7). From these data, the individual $\log \left(\mathrm{IAP}_{i}\right)$ is estimated after Eq. (5) and the results are compiled in Table 7. Using the corresponding $\log \left(K_{\mathrm{sp}, i}\right)$ (Table 6), the individual saturation indices are calculated after Eq. (6). Results are tabulated in the lower part of Table 7.

$$
\begin{gathered}
\log \left(\mathrm{IAP}_{i}\right)=\log \left({ }^{\mathrm{a}} \mathrm{REE}^{3+}\right) \times 2+\log \left({ }^{\mathrm{a}} \mathrm{CO}^{32-}\right) \times 3 \\
\mathrm{SI}_{i \text {-carb }}=\log \left(\mathrm{IAP}_{i}\right)-\log \left(K_{\mathrm{sp}, i}+\log \left({ }^{\mathrm{a}} \mathrm{REE}_{i}^{3+}\right)-\log \left(\Sigma^{\mathrm{a}} \mathrm{REE}^{3+}\right)\right)
\end{gathered}
$$

Index $i$ refers to the $\mathrm{REE}^{3+}$ involved in the experiment.

To estimate the saturation indices of the entirety of REE carbonates, the respective $\log \left(\mathrm{IAP}_{\mathrm{carb}}\right)$ and $\log \left(K_{\mathrm{sp}}, \Sigma_{\mathrm{REY}}\right)$ are estimated after Eqs. (7) and (8). This activity product can hardly be lower than $K_{\mathrm{sp}}$ of La but could be higher than $K_{\mathrm{sp}}$ of Lu.

Dealing with the entirety of REY is limited by the unawareness of the corresponding solubility product of the whole suite, $\log K_{\mathrm{sp}, \Sigma \mathrm{REY}}$, a value that cannot be determined and is therefore approximated by the sum of individual $K_{\mathrm{sp}}$ weighted by the corresponding activity fraction of $\mathrm{REY}^{3+}$ species in solution (Table 7). SI values of the entirety of REY carbonates are approximated in Table 7 , in which $\log \left(\operatorname{IAP}_{\Sigma \mathrm{REY}}\right)$ of REY carbonates are estimated from $\log \left(\Sigma^{\mathrm{a}} \mathrm{REY}^{3+}\right)$ and $\log \left({ }^{\mathrm{a}} \mathrm{CO}_{3}{ }^{2-}\right)$ obtained by PHREEQC and its "llnl" database (Parkhurst and Appelo 2013). $\log \left(\mathrm{IAP}_{\Sigma \mathrm{REY}}\right)$ of the entirety of REE carbonates is given by $\left(\log \left({ }^{\mathrm{a}} \Sigma \mathrm{REY}{ }^{3+}\right) \times\right.$ $2+3 \times \log \left({ }^{\mathrm{a}} \mathrm{CO}_{3}{ }^{2-}\right)$. The derived values of $\mathrm{SI}_{\Sigma \mathrm{REY}}=\log \left(\mathrm{IAP}_{\Sigma \mathrm{REY}}\right)-\log \left(K_{\mathrm{sp}, \Sigma \mathrm{REY}}\right)$ of the $\Sigma \mathrm{REY}$ carbonate are given in detail in Table 7 and are summarized in Table 3. The entirety of REY carbonates is supersaturated in Terakado and Masuda's and Zhong and Mucci's experiments.

$$
\begin{gathered}
\log \left(\operatorname{IAP} \Sigma_{\mathrm{REY}}\right)=\log \left(\Sigma^{\mathrm{a}} \mathrm{REE}^{3+} \times 2+\log \left({ }^{\mathrm{a}} \mathrm{CO}_{3}^{2-}\right) \times 3\right. \\
K_{\mathrm{sp}, \mathrm{REY}}=\Sigma\left(K_{\mathrm{sp}, i} \times\left[{ }^{\mathrm{a}} \mathrm{REE}_{i}^{3+}\right] /\left[\Sigma^{\mathrm{a}} \mathrm{REE}_{i}^{3+}\right]\right)
\end{gathered}
$$

The saturation indices SI for $\Sigma$ REE carbonate, $\mathrm{SI}_{\Sigma \mathrm{REY}}$, follow from Eq. (9). The positive $\mathrm{SI}_{\Sigma \mathrm{REY}}$ of the $\Sigma^{\alpha} \mathrm{REE}^{3+}$ is highlighted in the lower part of Table 7.

$$
\mathrm{SI}_{\Sigma \mathrm{REY}}=\log \left(\mathrm{IAP}_{\Sigma \mathrm{REY}}\right)-\log \left(K_{\mathrm{sp}},\right)
$$




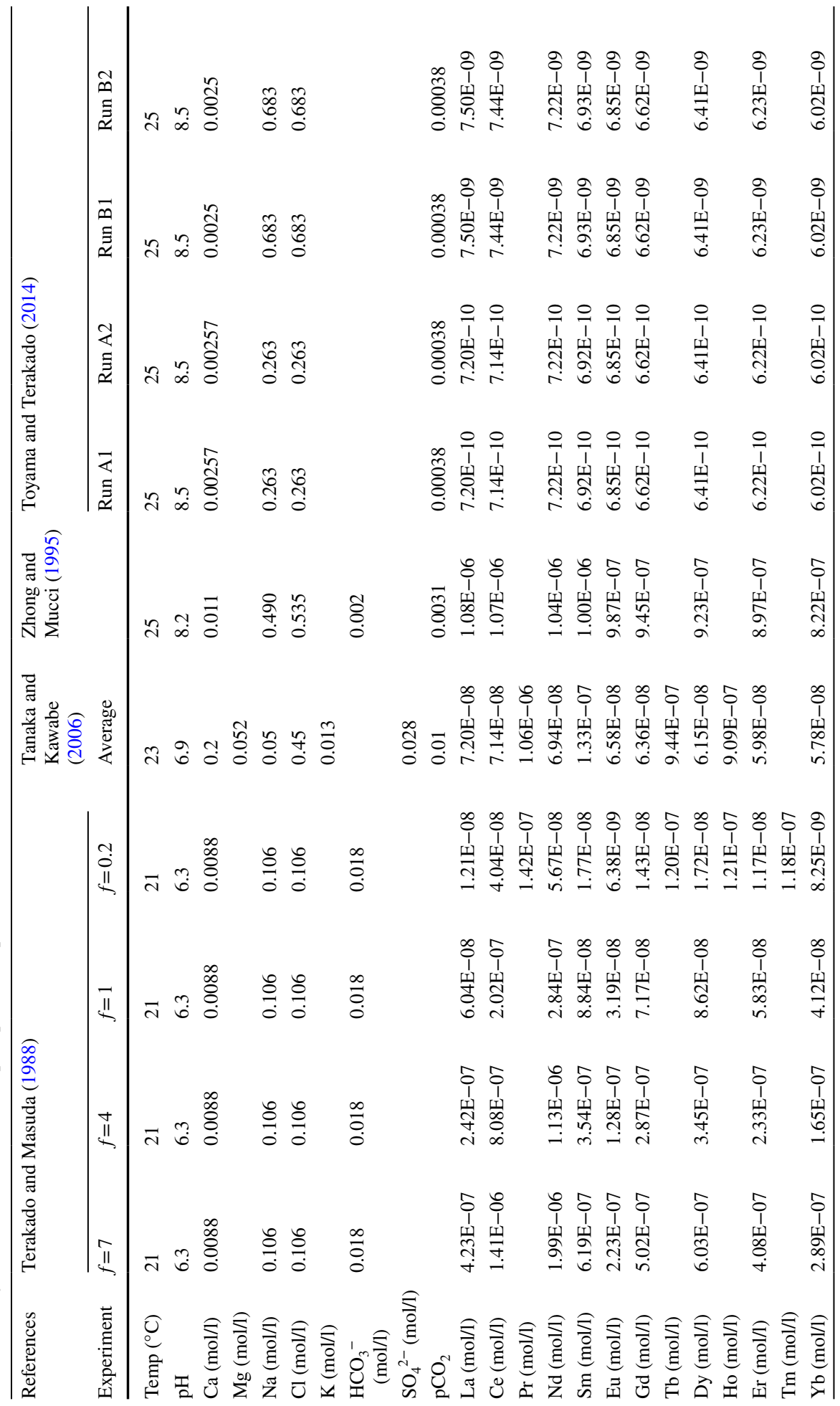




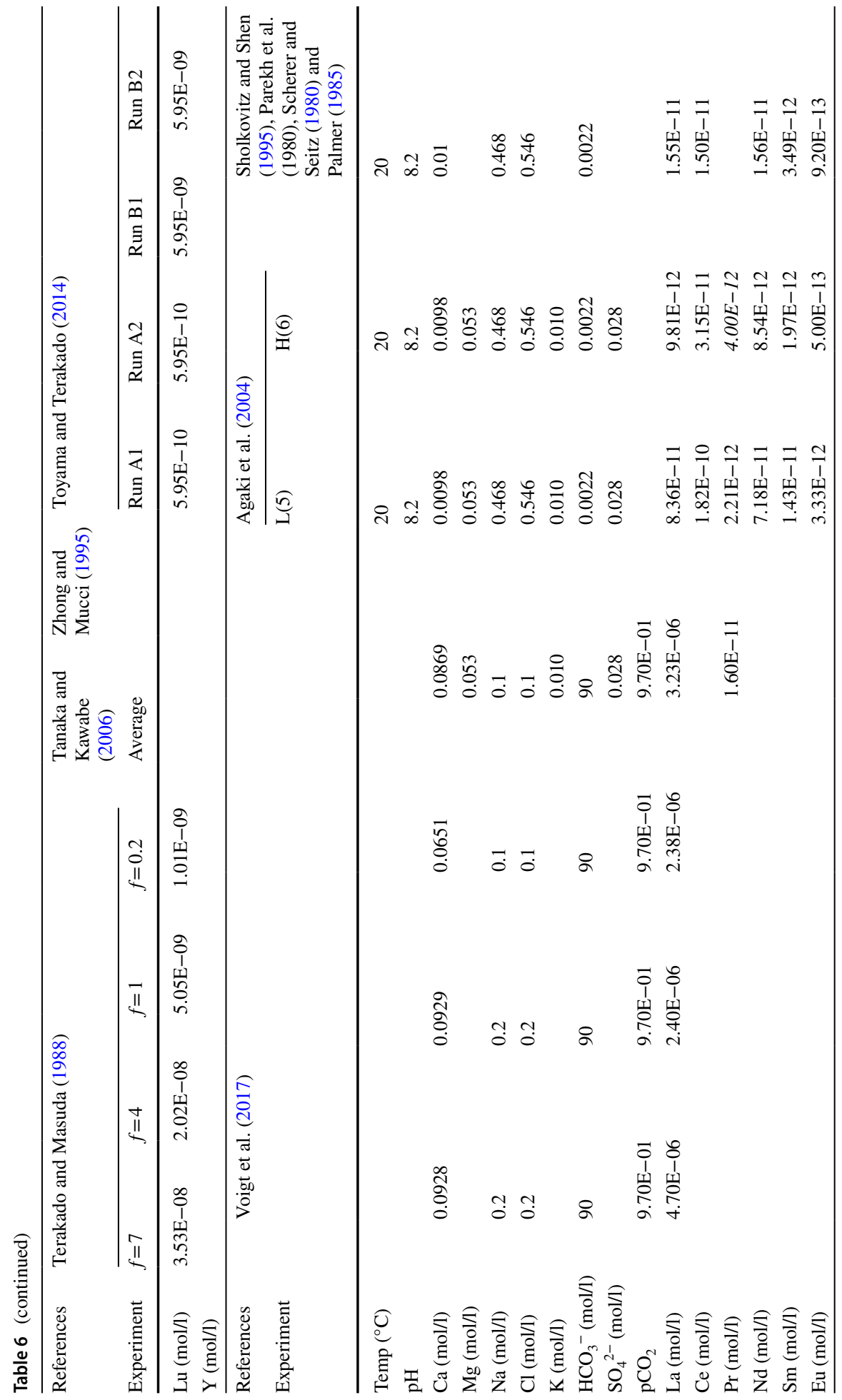




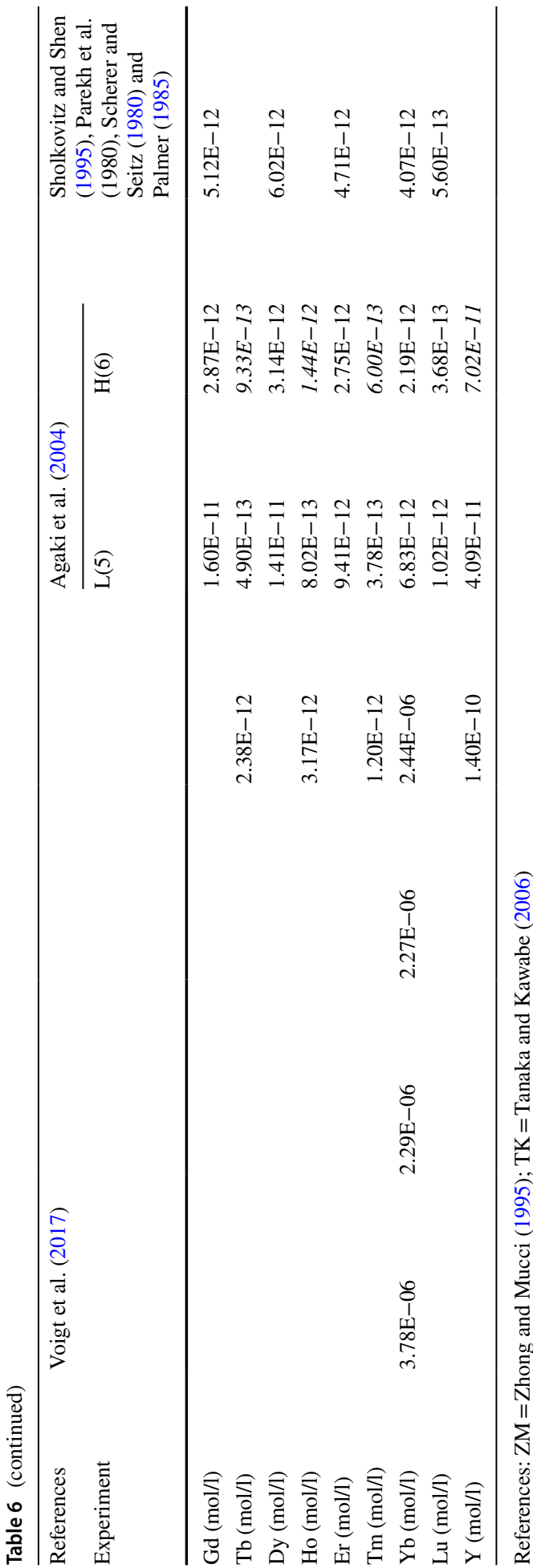




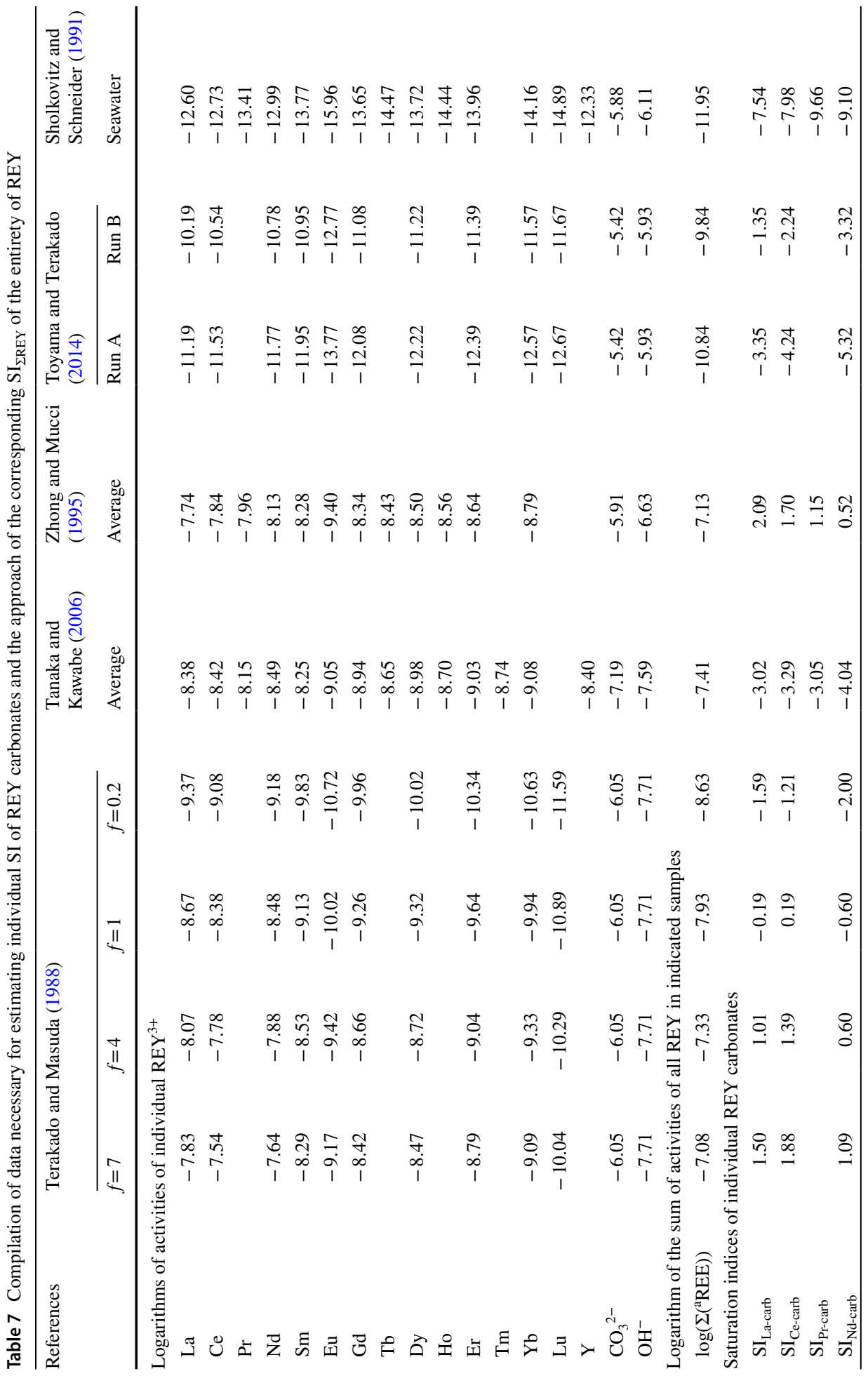




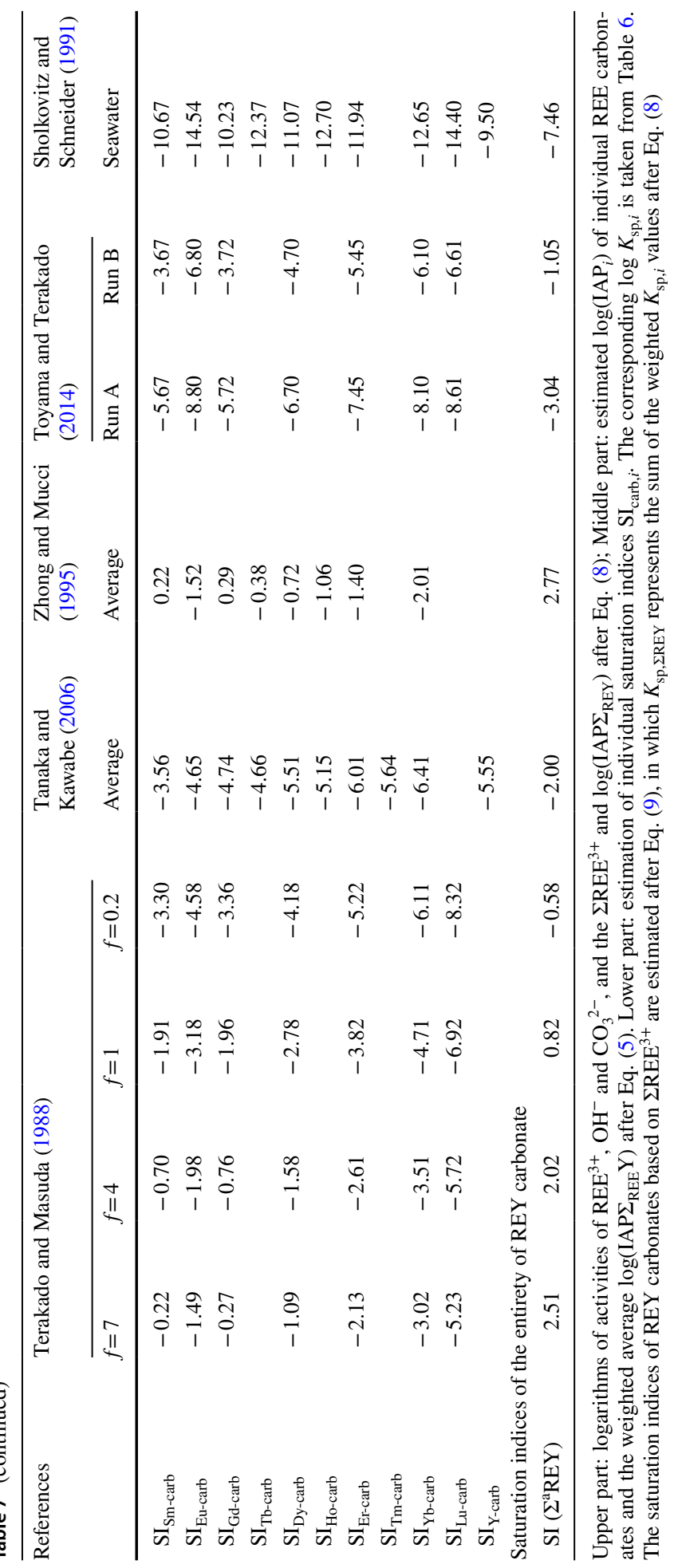




\section{Appendix 3}

\section{See Table 8.}

Table 8 Log $K_{\mathrm{sp}}$ of individual REE carbonate and hydroxides (Spahiu and Bruno 1995)

\begin{tabular}{llll}
\hline & $\begin{array}{l}\mathrm{REE}_{2}\left(\mathrm{CO}_{3}\right)_{2} \\
\text { crystalline }\end{array}$ & $\begin{array}{l}\mathrm{REE}(\mathrm{OH})_{3} \\
\text { amorphous }\end{array}$ & $\begin{array}{l}\mathrm{REE}(\mathrm{OH})_{3} \\
\text { crystalline }\end{array}$ \\
\hline $\mathrm{La}$ & -35.3 & -18.5 & -21.7 \\
$\mathrm{Ce}$ & -35.1 & -20.8 & -22.1 \\
$\mathrm{Pr}$ & -34.8 & -20.9 & -22.4 \\
$\mathrm{Nd}$ & -34.5 & -21.5 & -23.9 \\
$\mathrm{Sm}$ & -34.5 & -23.4 & -25.5 \\
$\mathrm{Eu}$ & -35 & & -26.9 \\
$\mathrm{Gd}$ & -34.7 & -24 & -26.4 \\
$\mathrm{~Tb}$ & -34.2 & -23.2 & -26.3 \\
$\mathrm{Dy}$ & -34 & -24.5 & -26.1 \\
$\mathrm{Ho}$ & -33.8 & -24.2 & -26.6 \\
$\mathrm{Er}$ & -33.6 & -23 & -27 \\
$\mathrm{Tm}$ & -33.4 & -24.7 & -27 \\
$\mathrm{Yb}$ & -33.3 & -23 & -27.3 \\
$\mathrm{Lu}$ & -33 & -23 & -27.5 \\
$\mathrm{Y}$ & -32.8 & -23 & -24.5 \\
\hline
\end{tabular}

\section{References}

Agaki T, Hashimoto Y, Fu FF, Tsuno H, Tao H, Yl Nakano (2004) Variation of the distribution coefficients of rare earth elements in modern coral-lattices: species and site dependence. Geochim Cosmochim Acta 68:2265-2273

Bau M, Dulski P (1995) Evolution of yttrium-holmium systematics of seawater through time. Min. Mg. 58A:61-62

Bruland KW, Lohan MC (2003) Controls of trace metals in seawater. In: Holland HD, Turekian KK (eds) Treatise on geochemistry, vol 6. Elsevier, Amsterdam, pp 23-47

Busenberg E, Plummer LN (1985) Kinetics and thermodynamic factors controlling the distribution of $\mathrm{SO}_{4}{ }^{2-}$ and $\mathrm{Na}^{+}$in calcites and selected aragonites. Geochim Cosmochim Acta 49:713-725

Cesbron F (1989) Mineralogy of rare-earth elements. In: Möller P, Cerny P, Saupe F (eds) Lanthanides, tantalum and niobium. Springer, Berlin, pp 3-26

Doener HA, Hoskins WM (1925) Co-precipitation of radium and barium sulfates. J Amer Chem Soc 47:662-675

Henderson LM, Kracek FC (1927) The fractional precipitation of barium and radium chromates. Am Chem Soc 49:738-749

Johannesson KH, Stezenbach KJ, Hodge VF (1997) Rare earth elements as geochemical tracers of regional groundwater mixing. Geochim Cosmochim Acta 61:3605-3618

Kim P, Anderko A, Navrotzki A, Riman RE (2018) Trends in structure and thermodynamic properties of normal rare earth carbonates and rare earth hydroxycarbonates. Minerals. https://doi.org/10.3390/ $\min 8030106$

Lakstanov LZ, Stipp SLS (2004) Experimental study of europium(III) coprecipitation with calcite. Geochim Cosmochim Acta 68:819-827

Miura N, Asahara Y, Kawabe I (2004) Rare earth element and Sr isotopic study of the Middle Perminan limestone-dolostone sequence in Kuzuu area, central Japan: seawater tetrad effect and Sr isotopic signature of seamount-type carbonate rocks. J Earth Planet Sci Nagoya Univ 51:11-35 
Möller P (1973) Determination of the composition of surface layers of calcite in solutions containing $\mathrm{Mg}^{2+}$. J Inorg Nucl Chem 35:395-401

Möller P, De Lucia M (2019) The impact of $\mathrm{Mg}^{2+}$ ions on equilibration of $\mathrm{Mg}-\mathrm{Ca}$ carbonates in groundwater and brines. http://eartharxiv.org/az39t. https://doi.org/10.31233/osf.io/az39t

Möller P, Rajagopalan G (1976) Changes of excess free energies in the crystal growth process of calcite and aragonite due to presence of $\mathrm{Mg}^{2+}$ ions in solution. Z Physik. Chem NF 99:187-198

Möller P, Sastri CS (1973) Exchange studies on single crystals of calcite. Inorg Nucl Chem Lett 9:759-763

Möller P, Sastri CS (1974) Estimation of the number of surface layers of calcite involved in $\mathrm{Ca}-{ }^{45} \mathrm{Ca}$ isotopic exchange with solution. Zt Physik Chem NF 89:80-87

Möller P, Sastri CS (2016) Cycling of calcite and hydrous metal oxides and chemical changes of major elements and REE chemistry in monomictic hardwater lake: impact on sedimentation. Chemie der Erde 76:133-148

Möller P, Rosenthal E, Dulski P, Geyer S, Guttman J (2003) Rare earths and yttrium hydrostratigraphy along the lake Kinneret-Dead Sea-Arava transform fault, Israel and adjoining territories. Appl Geochem 18:1613-1623

Moulin P, Roques H (2003) Zeta potential measurements of calcium carbonate. J Colloid Interface Sci 261:115-126

Palmer MR (1985) Rare earth elements in foraminifera tests. Earth Planet Sci Lett 73:285-298

Parekh PP, Möller P, Dulski P, Bausch WM (1977) Distribution of trace elements between carbonate and non-carbonate phases of limestone. Earth Planet Sci Lett 34:39-50

Parkhurst DL, Appelo CAJ (2013) Description of input and examples for PHREEQC version 3 - A computer program for speciation, batch-reaction, one-dimensional transport, and inverse geochemical calculations. U.S. Geological Survey Techniques and Methods, book 6, chap. A43, p 497. https:// pubs.usgs.gov/tm/06/a43/. Accessed 02 Nov 2020

Pokrovski OS, Sholkovitz J (2001) Kinetics and mechanism of dolomite dissolution in neutral to alkaline solutions revisited. Am J Sci 301:597-626

Scherer M, Seitz H (1980) Rare earth element distribution in holocene and pleistocene corals and their redistribution during diagenesis. Chem Geol 28:279-289

Shannon RD (1976) Revised effective ionic radii and systematic studies of interatomic distances in halides and chalcogenides. Acta Crystallogr A 32:751-767

Shields GA, Webb GE (2004) Has the REE composition of seawater changed over geological times? Chem Geol 204:103-107

Sholkovitz ER, Schneider DL (1991) Cerium redox cycles and rare earth elements in the Saragasso Sea. Geochim Cosmochim Acta 55:2737-2743

Sholkovitz ER, Shen GT (1995) The incorporation of rare earth elements in modern coral. Geochim Cosmochim Acta 59:2749-2756

Siebert C, Möller P, Geyer S, Kraushaar S, Dulki P, Guttman J, Subah A, Rödiger T (2014) Thermal waters in the Lower Yarmouk Gorge and their relation to surrounding aquifers. Chemie der Erde/Geochem 74:425-441

Smith RM, Martell AE (1976) Critical stability constants: inorganic complexes, vol 4. Plenum Press, New York

Spahiu K, Bruno J (1995) A selected thermodynamic database for REE to be used in HLNM performance assessment exercises. MBT Technologia Ambiental, Cerdanyola, Spain Technical Report 95-35; available through Swedish Nuclear Fuel and Waste Management CO, Stockholmn

Tanaka K, Kawabe I (2006) REE abundance in ancient seawater inferred from marine limestones and experimental REE partition coefficients between calcite and aqueous solution. Geochem J 40:425-435

Tanaka K, Miura N, Asahara Y, Kawabe I (2003) Rare earth element and strontium isotopic study of seamount-type limestone in mesozoic accretionary complex of southern Chichibu Terrane, central Japan: implication for incorporation process of seawater REE into limestones. Geochem J 37:163-180

Tanaka K, Ohta A, Kawabe I (2004) Experimental REE partitioning between calcite and aqueous solutions at $25{ }^{\circ} \mathrm{C}$ and $1 \mathrm{~atm}$ : constraints on the incorporation of seawater REE into seamount-type limestones. Geochem J 69:103-110

Terakado Y, Masuda A (1988) The coprecipitation of rare-earth elements with calcite and aragonite. Chem Geol 69:103-110

Toyama K, Terakado Y (2014) Experimental study of rare earth element partitioning between calcite and sodium chloride solution at room temperature and pressure. Geochem J 48:463-477

Toyama K, Terakado Y (2019) Estimation of the practical partitiom coefficients of rare earth elements between limestone and seawater: discussion and application. Geochem J 53:139-150

Voigt M, Mavromatis V, Oelkers EH (2017) The experimental determination of REE partition coefficients in water-calcite system. Chem Geol 462:30-43 
Webb GE, Kamber BS (2000) Rare earth elements in Holocene reefal microbialites: a new shallow seawater proxy. Geochim Cosmochim Acta 64:1557-1565

White AF (1975) Sodium and potassium coprecipitation in calcium carbonates. Ph.D. dissertation, Northwestern University, Evaston, IL, USA

Wyndam T, McCulloch M, Fallon S, Alibert C (2004) High-resolution coral records of rare earth elements on coastal seawater: biochemical cycling and a new environment proxy. Geochim Cosmochim Acta 68:2067-2080

Zhong S, Mucci A (1993) Calcite precipitation in seawater using a constant addition technique: a new overall reaction kinetic expression. Geochim Cosmochim Acta 57:1409-1417

Zhong S, Mucci A (1995) Partitioning of rare earth elements (REEs) between calcite and seawater solutions at $25^{\circ} \mathrm{C}$ and $1 \mathrm{~atm}$, and high dissolved REE concentrations. Geochim Cosmochim Acta 59:443-453

Publisher's Note Springer Nature remains neutral with regard to jurisdictional claims in published maps and institutional affiliations. 